Polgári Szemle, 16. évf. 1-3. szám, 2020, 287-313., DOI: 10.24307/psz.2020.0718

Jakab Nóra - Prugberger Tamás - Tóth Hilda

\title{
A magyar munka- és a közszolgálati jogi szabályozás alakulása a rendszerváltás után
}

\section{Developments in Hungarian Labour and Public Service Law Since the Change of Regime}

Összefoglalás

A tanulmány a rendszerváltást követố munka- és közszolgálati jog kodifikációjával foglalkozik. Külön részletezi az 1992. évi törvényekkel kialakított szabályrendszert, a kollektív munkajogi szabályozást, az individuális munkajogi rendelkezéseket, továbbá a közszolgálat szabályozását. A tanulmány második részében a 2012. évi Munka törvénykönyve főbb rendelkezéseit és a változásokat vizsgáljuk meg, különös tekintettel a jogalanyiságra, a munkaviszony megszüntetésére és a kártérítési felelôsségre vonatkozó szabályokat. Végezetül kitérünk a felsôoktatás részbeni alapítvánnyá történô átalakítására és a kulturális intézményeknél a közalkalmazotti jogviszony munkaviszonnyá alakulására.

Kulcsszavak: munka- és közszolgálati jog kodifikációja, kollektív munkajog, individuális munkajog, 2012. évi Munka törvénykönyve, megszüntetés, kártérítési felelôsség, jogalanyiság

Prof. Dr. Prugberger Tamás DSc, professor emeritus, Miskolci Egyetem (prugberger.tamas@t-online.hu), DR. TóTH Hilda PhD, egyetemi docens, Miskolci Egyetem (toth.hilda@uni-miskolc.hu), DR. HABIL JAKAB NóRA egyetemi docens, rektorhelyettes, Miskolci Egyetem (jakabn81@gmail.com). 
Jakab Nóra - Prugberger Tamás - Tóth Hilda: A magyar munka- és a közszolgálati...

\section{Summary}

The study deals with the codification of labour and public service law following the change of regime. Specifically, it details the rules established by the relevant act adopted in 1992 on collective labour, the individual labour law regulations and the regulation on public service. In the second part of the study, a description is given of the main provisions of the 2012 Labour Code and its changes, in particular the rules on legal personality, the termination of employment and liability for damages. Finally, it is pointed out that the transformation of higher education into a partial foundation and of the legal perspectives of employment at cultural institutions has resulted in turning civil servants' labour law relationship into regular employment.

Keywords: codification of labour and public service law, collective labour law, individual labour law, Labour Code of 2012, termination, liability for damages, legal personality

\section{ELÓZMÉNYEK}

Az 1990. évi rendszerváltást megelőzóen és azt követően még egy évig Magyarországon a Munka törvénykönyveként (Mt.) az 1967:II. tv. volt hatályban, amely csak az individuális munkajogot, a munkaviszonyt szabályozta, azt is úgy, hogy nemcsak a gazdasági élet munkajogi viszonyait rendezte, hanem a közalkalmazottak és a köztisztviselók munkaviszonyát is. Ennek oka, hogy a vállalati szféra túlnyomó része állami tulajdonban volt, és az akkori ideológia szerint az állami vállalat volt a gazdasági igazgatás legalsó szintje (Ficzere, 1970:87). Ennélfogva a vállalatnál munkaviszonyban állók is tulajdonképpen közalkalmazottak voltak. Azok nem tartoztak ide, akik a munkaszövetkezetekben dolgoztak. Az ô tagsági viszonyukat a mezógazdasági szövetkezeti törvény (1967:III. tv.) egyik fejezete (VIII.), míg az ipari szövetkezetek esetében az Ipari Szövetkezetek Országos Szövetsége által kiadott munkaügyi szabályzatminta alapján, az egyes ipari szövetkezetek által elkészített, és a közgyúléssel jóváhagyott Munkaügyi Szabályzat szabályozta. Ennek alapján volt általános az az elmélet, miszerint a szövetkezeti tagsági viszony három részből áll: tagsági szervezeti, vagyoni és személyes közremúködési viszonyból, mely utóbbinak egyik formája a tagi munkavégzés lehet (Hegedûs, 1973:34).

Az akkori Mt. kollektív munkajogot nem szabályozott. Egy rövid fejezet foglalta csak össze a szakszervezetek jogállását és feladatait. A szakszervezetek jogállása az államtól függött, mivel a Szakszervezetek Országos Tanácsa (SZOT) minisztériumi státuszban volt, elnöke pedig a Minisztertanácsban foglalt helyet. Ennélfogva a szakszervezet nem munkavállalói érdekvédelmi feladatot látott el, hanem arra ügyelt, hogy a munkavállalók teljesítsék az államnak az egyes vállalatokkal és azok dolgozóival szembeni gazdasági elvárásait. Azt, hogy külön munkavállalói érdekvédelemre nincs szükség, alátámasztotta Venediktov szovjet jogtudós kettős kollektíva elmélete, mely szerint 
egyfelôl minden állami vállalat valamennyi állampolgárnak, másfelől pedig a vállalatnál dolgozók kollektívájának a tulajdona. Emiatt pedig ellentét elméletileg nem áll fenn a vállalati vezetés és a dolgozói kollektíva között (Venediktov, 1948). Mivel ez okból a munkaküzdelem létét a hivatalos munkajogelmélet tagadta, sztrájktörvény a „szocialista” államokban, így Magyarországon sem létezett.

Hogy ez mennyire nem volt igaz, a kommunista rendszer utolsó két évében sorra alakultak az alternatív szakszervezetek, és léptek ki a dolgozók a SZOT alá tartozó szakszervezetekból, amelybe korábban jogilag nem, ténylegesen azonban be kellett lépni. Akik kiléptek és/vagy átléptek valamelyik újonnan alakult alternatív szakszervezetbe, fegyelmi elbocsátás veszélyének tették ki magukat. Az ilyen ügyekben a munkaügyi bíróságok sem mertek ítéletet hozni, hanem a rendszerváltásig fektették azok iratait (Prugberger, 1992; Prugberger-Kenderes-Mélypataki, 2012; Prugberger-Nádas, 2015:59-60).

A rendszerváltást megelőzố utolsó két évben, az események sodrában, a kormányzat kénytelen volt külön törvénnyel bevezetni a dolgozói részvényt, hogy érdekeltté tegye a munkavállalókat a gazdálkodásban. Törvényt alkotott a kollektív keretszerzôdésról, amely több évre szólt, és a gazdasági, valamint a bérviszonyok alakulásának a függvényében kötötték volna meg évenként a kollektív szerződéseket. Ekkor már hatékonyan múködtek az alternatív szakszervezetek (Kenderes-Prugberger-Tatár, 1989:23). Megszületett a sztrájkról szóló, nem a legsikerültebb 1989:VII. tv. is (TatárKenderes-Prugberger, 1989; Prugberger-Tatár, 1994).

\section{A RENDSZERVÁLTÁST KÖVETÓ ELSỐ MUNKA- ÉS KÖZSZOLGÁLATI JOGI KODIFIKÁCIÓ SORSA ÉS ÉRTÉKELÉSE}

\section{A szabályozás általános elvei}

Az 1990. évi rendszerváltással hatalomra került elsố polgári kormány, az Antall-Boross-kormány által irányított Munkaügyi Minisztérium és Belügyminisztérium azonnal nekilátott a munkával és a közszolgálattal kapcsolatos jogviszonyok újrakodifikálásának. A Munka törvénykönyve (Mt.) az 1992. évi XXII. törvénnyel, a Köztisztviselók jogállásáról szóló törvény (Ktv.) az 1992. évi XXIII. törvénnyel, míg a Közalkalmazottak jogállásáról szóló törvény (Kjt.) az 1992. évi XXXIII. törvénnyel lépett hatályba 2012. július 1-jén. A munka- és a szolgálati viszonyok jogi szabályozásának ezzel a rendszerével tulajdonképpen a nyugat-európai megoldástól eltérő szabályozási rendszer érvényesült. E magyar trichotómiával szemben, hogy míg a gazdasági élet szolgálati viszonyait a munkajog, az állami (köz)szolgálat viszonyait a nyugat-európai országokban a közszolgálati jog rendezi, addig nálunk a közszolgálat kétfelé bomlik: akik nem hatósági jellegú közintézményekben dolgoznak, közalkalmazottként a Kjt. alá azok tartoznak, akik pedig hatósági intézményekben ügyintézói munkakört töltenek be, azokra a Ktv. vonatkozik. Ugyanakkor ez a szabályozás azért logikátlan, mert a hatóságoknál dolgozó fizikai munkások munkaviszonyban, nem pedig közalkalmazotti viszonyban állnak. E rendszer mögött a germán jogrendszernek egy következetlenül 
Jakab Nóra - Prugberger Tamás - Tóth Hilda: A magyar munka- és a közszolgálati...

végigvitt megoldása húzódik meg, mivel a germán jogrendszerhez tartozó államokban csak az ügyintézók a közhivatalnokok, és csak rájuk vonatkozik a közhivatalnoki törvény, míg az ügykezelók és a fizikai dolgozók szolgálati viszonyát a munkajog rendezi. Ezzel szemben a frankofón-latin jogrendszereknél mindenki, aki közintézménynél bármilyen munkakört lát el, legyen az hatósági vagy nem hatósági intézmény, illetve ügyintézôi, ügykezelối vagy fizikai munkakör, közalkalmazotti státuszban áll, és a közszolgálat státuszbiztonságát élvezi (Peine-Heinlein, 1999; Heerma van Voss, 2003:41; Balázs, 1992; Veszprémi, 2012a:17-36; Prugberger, 2013:334-340). A munka-, illetve a szolgálatijogviszony-rendezés mind a két nyugat-európai jogrendszernél dichotóm. A trichotóm magyar megoldás annak ellenére, hogy eltért a nyugat-európai, illetve az Európai Gazdasági Közösség tagállamainak dichotóm megoldásától, mégsem állt ellentétben az Európai (Gazdasági) Közösség jogával, és most sem áll ellentétben az európai uniós joggal, mert sem az EGK, sem az EK, sem az Európai Unió EU joganyaga nem érinti a tagállamok közszolgálati jogát. A rendeletek és az irányelvek ugyanis a privát és a gazdasági élet munkaviszonyára vonatkoznak, a közszolgálati jogra nem. A helyzet e tekintetben azóta sem változott.

A magyar munkajogi szabályozásnak a trichotóm, illetve a közszolgálatnak a dichotóm jellegét több szerzô is kritizálta (Kenderes-Prugberger, 1991; 1993; Kiss, 1988; 1998; Vadász, 2006, függelékben az egységes közszolgálati tv. tervezete; Horváth, 2009; Prugberger, 2010), ${ }^{2}$ törvényjavaslat is született, a német rendszer átvételét sugallva a közszolgálat szabályozásának egységesítésére. A mai divatos privatizációs áramlat hatására egyre többször elôtérbe került az a nézet, mely szerint a közalkalmazotti jogviszonyt az Mt.-ben kellene szabályozni (Prugberger, 2007), ami a két jogviszony eltérô jellege miatt hibás koncepció (Kenderes-Prugberger-Tatár, 1989; Tatár-Kenderes-Prugberger, 1989; Prugberger-Tatár, 1994). Ennek ellenére úgy tûnik, ez az irányzat erôsödik azáltal, hogy a 2010-et követô átfogó munka- és közszolgálati jogi újrakodifikálás, illetve átfogó módosítás a Kjt.-t az Mt.-hez közelítette. Ugyanakkor a „köztisztviselôi jogot” igyekszik a munkajogtól eltávolítani. Ezzel a szabályozás bár dichotómmá válna, azonban ellentmondásosan, a közalkalmazotti jogviszonynak a munkajogba való „terelése” miatt. Az egész probléma gyökere a rendszerváltást megelôzô helyzetben keresendó, mivel a területi (megyei és járási), valamint a települési közhivatalnokok egy különálló országos szerv, a Minisztertanács Tanácsszervek Osztályához tartozott, mely hivatalt még 1990 elôtt beolvasztották a Belügyminisztériumba, és így a közhivatalnokok annak joghatósága alá kerültek. A Belügyminisztérium pedig presztízskérdést csinált abból, hogy a köztisztviseloói törvényjavaslatot ne a Munkaügyi Minisztérium, hanem ô alkossa meg. Ennélfogva olyan helyzet jött létre, hogy csak a Kjt.-nek lett az Mt. általános háttérjogszabálya, a Ktv.-nek viszont nem.

\section{A kollektív munkajog szabályozása}

Az 1992-ben hatályba lépett Mt.-t tekintve, nyugat-európai mintára szabályozta a kollektív munkajog mindkét területét, az érdekegyeztetési, más néven a koalíciós jogot, benne a szakszervezetek jogait és kötelezettségeit, az országos érdekegyeztetést és a 
vállalati kollektív szerződést, valamint az üzemi alkotmányjogot, benne az üzemitanácsrendszert és az üzemi megállapodást. E kollektív munkaügyi szabályozással a magyar munkajogalkotás a közép- és kelet-európai posztkommunista országok élére került, mivel ezek az államok a munkajogi kódexeikbe szervesen nem illesztették be, csak késóbb tették meg ezt. Ezenkívül az üzemi tanácsot és az üzemi megállapodást a lengyelek kivételével egyik posztkommunista ország sem ültette át a saját jogrendszerébe, de a lengyelek is általános jelleggel, csak a közintézmények és az állami, valamint a közintézményi vállalatok területén, a gazdasági munkajog területén pedig csak szubszidiáriusan arra az esetre, ha a vállalatnál nem múködik szakszervezet (Prugberger, 1993).

Ugyanakkor a magyar kollektív munkajogi szabályozás meglehetôsen hiányosra és vegyes jellegúre sikeredett. Hiányos volt annyiban, hogy csak az országos érdekegyeztetési rendszert szabályozta, nem szólt viszont az ágazati és a területi érdekegyeztetésrôl, az országos ágazati és a területi kollektív szerzôdésrôl, a tripartit jelleggel múködô (állam, szakszervezeti és munkáltatói érdekképviseleti oldal) Országos Érdekegyeztetố Tanácsba bekerülés feltételeiről. A vállalati kollektív szerződés megkötésének a feltételeit, vagyis a reprezentativitást viszont nagyon demokratikusan rendezte. Kimondta ugyanis, hogy ha egy cégnél az üzemitanács-választásokon a munkavállalók 10\%-os szavazatát elért egy reprezentatív szakszervezet van, vagy ha több ilyen van, és vagy egyedül, vagy konföderációba lépve a többi hasonlóval, az üzemi tanácsválasztásokon több mint 50\%-ot elér, vagy együttesen elérnek, a kollektív szerződés megköthetô. Ha viszont a vállalatnál múködô több szakszervezet közül csak egy kíván kollektív szerzódést kötni, annak az üzemitanács-választásokon legalább 65\%-os eredményt kell felmutatnia. ${ }^{3}$ Ez a magyar megoldás sokkal jobb volt, mint az akkori csehszlovák megoldás, ahol a Kodeks pracy értelmében ismeretlen volt az országos kollektív szerződés a bérinfláció megelôzése érdekében, viszont a vállalatnál képviselettel rendelkezô valamennyi szakszervezet reprezentativitási kikötések nélkül részt vehetett a kollektív szerződés megkötésében. A sok ellentétes vélemény azonban kioltotta egymást, ezért sorra meghiúsultak a vállalati kollektívszerzôdés-kötések Csehszlovákiában (Kostecka, 1992:436).

Az országos érdekegyeztetés hiányos szabályozása azonban Magyarországon nem oldódott meg. A kodifikációs bizottságot irányító Pál Lajos az állami közremúködés nélküli, német kétoldalú (bipartit) országos ágazati érdekegyeztetési és kollektívszerződés-kötési rendszert akarta bevezetni, az országos szakszervezeti szövetségek azonban a francia-belga-holland-spanyol tripartit modell mellett szálltak síkra. Kompromisszumként az e modelleknél kialakított nemzeti munkatanács és ágazati, valamint területi bizottságok mintájára, először csak az Országos Érdekegyeztető Tanács (OÉT) megalakítására és az Mt.-be történt beemelésére került sor, amely elé csak három kérdést kellett kötelezốn bevinni: a minimálbér, a maximális munkaidô megállapítását, valamint a csoportos létszámleépítés szabályainak a módosítását. Egyébként a német bipartit érdekegyeztetési rendszer funkcionált volna.

Idôvel azonban a tripartit országos érdekegyeztetési rendszer vált általánossá. Az OÉT általánossá tette az országos munkaügyi kérdésekben való döntési hatáskörét, és mellette egy bürokratikus ügyintézô iroda alakult ki a Munkaügyi Minisztérium 
Jakab Nóra - Prugberger Tamás - Tóth Hilda: A magyar munka- és a közszolgálati...

keretében. Ugyanakkor nem oldódott meg az OÉT-be történô bekerülés reprezentativitáson alapuló feltételrendszere. Az alternatív szakszervezetek ugyanis nem voltak hajlandók kiadni tagjaik névsorát, okulva a már korábban említettekból. Ebben az idôszakban ugyanis az állami vállalatok privatizációja még nem indult meg. A viták során a régi szakszervezeti és politikusi munkáltatói nómenklatúra álláspontja gyôzött. Az érdekvédelmi szervezetek ingatlantulajdon-jogi aránya szerint állapították meg a reprezentativitást. Ennek alapján a munkáltatói érdekvédelmi szervezetek mindegyike tagja lett az OÉT-nek. Ezzel szemben a szakszervezeti szövetségeknél volt a szakszervezeti ingatlan vagyon tetemes hányada, míg az újonnan alakultaknál csak egész csekély, így a SZOT jogutódja, az MSZOSZ az OÉT-be 90\%-os reprezentativitással került be, míg a maradék 10\%-on osztozott a többi újonnan alakult szakszervezet (PrugbergerNádas, 2015:67-73). ${ }^{4}$

Az OÉT-be kerülés feltételét jelentô tripartit megállapodással megkötött ilyen reprezentativitás teljesen ellentétben állt a nyugat-európai, így a belga, a holland és a spanyol nemzeti tanácsi és ágazati, valamint területi ágazati bizottsági rendszerrel. Az elôbbi kettônél törvényi elôírással paritásos alapon azok a szakszervezeti és munkáltatói szövetségek kerülhetnek be a nemzeti munkaügyi (belga), illetve a nemzeti gazdasági és szociális (holland) tanácsba, valamint az ágazati bizottságokba, amelyek egyedül vagy konföderációba lépve gazdasági ágazatukat több mint 50\%-os mértékben képviselik, valamint a törvényben meghatározott minimális taglétszámmal rendelkeznek. Ezzel szemben az utóbbinál alulról felfelé, munkavállalói oldalon az üzemitanács-választás eredményének függvényében, munkáltatói oldalon pedig a tagi számaránytól függve, a legalsó szinttôl felfelé, automatikus szelektálási alapon kerülnek be a koalíciós partnerek a területi, valamint az országos ágazati munkaügyi bizottságba, végül pedig a nemzeti munkaügyi tanácsba (Bódis, 1994; Rens, 1992; Borbély, 1994; Ojeda Aviles-Perez, 1989). A magyar jogi rendezésben itt is egy kettôsség érvényesült, mivel vállalati szintig a szakszervezeti reprezentációt a spanyol jellegú üzemitanács-választás határozta meg, vagyis a reprezentativitás megállapítása a spanyolhoz hasonlóan alulról felfelé történt, onnantól pedig épp fordítva, a belga-holland modell szerint felülrôl lefelé, azonban paritásos képviselet nélkül egyenlôtlen feltételek mellett, és nem jogszabályi, hanem csak megállapodásos alapon. Ebból a szempontból a bolgár munkajog idóben és megoldásban is lényegesen megelózött bennünket, ahol a szintén tripartit összetételú nemzeti munkatanács teljesen megfelelt a belga-holland modellnek (Sredkova, 1995:256-257). Magyarországon hosszan elnyúló tárgyalások után csak 2009-re sikerült a tripartit érdekegyeztetési rendszert lényegében a holland megoldás átvételével tetô alá hozni. Ugyanis a paritásos képviselet reprezentatív szabályainak bevitele mind a Nemzeti Munkástanácsról visszakeresztelt Országos Érdekegyeztetô Tanácsba (OÉT), mind az ágazati érdekegyeztetés fórumrendszerébe két jogszabály (2009:LXXIII. és LXXIV. tv.) megalkotásával történt. Ilyen módon sikerült tételes jogilag is megalapozva, paritásos reprezentatív feltételek között megállapított taglétszám, és egyedüli vagy konföderációs ágazati képviselet mellett kialakítani az OÉT-be és az ágazati/területi párbeszédbizottságokba kerülés feltételeit, valamint az országos tripartit és az ágazati/területi bipartit érdekegyeztetést bevezetni (Prugberger-Nádas, 2015:69-71, 73-74, 77-81). 


\section{Polgári Szemle · 16. évfolyam 1-3. szám}

Áttérve az üzemi tanácsra, annak unikális formáját a német modell alapulvételével vezette be az 1992. évi Mt. A kettô között azonban lényeges különbség van. Míg a német üzemi tanácsnak széles körú beleszólási joga van a munkáltató döntésébe (együttdöntési jogkör) a munkakörülmények kialakításával, a munkadíjazással, a munkavédelemmel és a munkaegészségüggyel kapcsolatban, addig a magyar üzemi tanács együttdöntési joga az 1992. évi Mt. szerint csak a jóléti üzemi intézmények igazgatására, valamint a szociális alapból való részesedés meghatározására terjedt ki. Minden más kérdésben az üzemi tanácsnak csak véleményezési joga volt, és van ma is, amit azonban ha a munkáltató nem tart be, nincs komoly szankciója. Az üzemi tanácsi választási rendszerben a szakszervezeti közremúködés nélküli rendszer már kombinálódott a belga, holland, francia és spanyol rendszerrel, ahol a jelölteket nem a leköszönô üzemi tanács által választott bizottság, hanem a szakszervezetek jelölik. A magyar szabályozás vegyes rendszert vezetett be, ahol elsôsorban közvetlenül a szakszervezetek jelöltek, míg ötven munkavállaló szintén közvetlenül jelölhetett egy személyt. ${ }^{5}$

\section{Az individuális munkajogi rendelkezések}

Ami az 1992. évi Mt. individuális munkajogi szabályait illeti, azok összhangban álltak azzal a nyugat-európai szabályozási rendszerrel, amelyet a jóléti állam eszméje (welfare society \& state) és a szociális piacgazdasági rendszer hatott át. Az 1992. évi Mt. eredeti szövege még biztosította a munkavállalók részére majdnem valamennyi szociális minimumvédelmi elôírást, amit a nyugat-európai államok biztosítottak a saját munkavállalóiknak. E munkavédelmi szociális jogok azonban az Mt.-módosítások során fokozatosan gyengültek, illetve szúkültek. Ez azzal állt összefüggésben, hogy az EK, majd pedig az EU a közép-európai bóvítéssel az újonnan becsatlakozó államok számára nem kívánta megadni azokat a szociális piacgazdasági rendszerból és jóléti államiságból fakadó szociális jogokat, amelyeket a régi tagállamok munkavállalói számára az EGK idôszakában irányelvek alapján megalkotott. Ezért a korábbi irányelvek fokozatos módosítására vagy lecserélésére kerül sor, amelyekben jelentôsen szúkítik a munkavállalók érdekeit védô szociális minimálstandardokat. Az új tagállamoknak az így módosított vagy kicserélt európai uniós munkajogi normákkal kell összhangba hozni saját nemzeti munkajogukat, miközben a régi tagállamok legtöbbje alig vagy semmit sem változtatott a saját munkajogi előírásain. ${ }^{6}$

Az elsố nagyobb lélegzetú módosítást a balliberális Horn-kormány valósította meg 1995-ben, amikor a munkavállaló a munkahelyrôl való valamennyi jogszerú távolléte esetére (szabadság, betegszabadság, állampolgári kötelesség teljesítése stb.) az átlagkereset-térítés helyett az annál alacsonyabb összegú „távolléti díj”-at vezette be. Egyúttal eltörölték a munkaerôt védó szabályt, mely szerint ugyanazon a munkahéten belül történố túlmunka (túlórázás) esetén a túlmunka ideje nem érheti el a fôszabályként megállapított napi négy órát. Majd a 2001. évi átfogó módosítással lehetôvé vált, hogy a munkavállaló a heti 48 órát meghaladóan is kivételesen munkába állítható legyen, ha ezt a technológia vagy gazdasági érdek indokolja. A túlmunka heti korlátja megszúnt, és csak évi 250 munkaórában korlátozták, ami kollektív szerzôdéssel felemelhe- 
Jakab Nóra - Prugberger Tamás - Tóth Hilda: A magyar munka- és a közszolgálati...

tô 300 munkaórára. Irányelvi alapon bevezették a „munkaidôkeret” (referenciaidôszak) rendszerét, amely maximum hat hónap lehet, ezt a 2001. évi módosítás olyan módon vezette be, hogy kollektív szerzôdés nélkül a munkaidókeret 4 hónap lehet, kollektív szerzôdéssel 6 hónapra meghosszabbítható. Ezzel szemben az EU régi tagállamai továbbra is megtartották azt a megoldást, hogy a munkaidókeret nem lehet több egy hónapnál.

Szólni kell arról is, hogy a Európai Gyáriparosok és Munkáltatók Szervezeteinek Szövetsége (UNICE) és az Állami és Közszolgáltatási Vállalatok Európai Központja (CEEP) a folyamatosan üzemelô, a több múszakos, az idényjellegú munkahelyeken és a családi vállalkozásoknál, valamint a készenléti munka, továbbá az ügyelet esetében be akarta vezetni a heti 60 munkaóra lehetôségét. Az ilyen munkavégzéseknél a két munkanap közötti 11 órában meghatározott pihenôidôt le lehetett volna csökkenteni 8 órára. E tervbe vett szabályok átmenetileg bekerültek az Mt.-be. Minthogy az Európai Szakszervezeti Szövetség (ETUC) erôteljes ellenállása folytán e tervet csak részben sikerült a munkaidôról szóló irányelvbe betenni, ezért a magyar Mt.-ben a heti 52 órás munkaidő lehetôsége csak az idénymunka, a családi munkavégzés, valamint a készenlét és az ügyelet esetében maradt meg. Viszont a fent említett valamennyi eset fennállásánál továbbra is le lehet szorítani a két munkanap közötti pihenôidôt 8 órára. ${ }^{7}$ Problémás továbbá a magyar munkajogi rendezésben az is, hogy miközben az Európai Törvényszék több ítéletében is kimondta, hogy az ügyeletet, amely alatt a munkahelyen kell tartózkodni (NZA, 2000; NZA, 2004; Prugberger-Nádas, 2014:230), és most már esetenként a készenlétet is rendes munkaidőnek kell tekinteni (Zaccaria, 2013; Fodor, 2016; Sipka-Zaccaria, 2016), amelyre értelemszerúen rendes munkabér jár, a magyar Mt. a készenlétre csak a munkabér 20\%-át, az ügyeletre pedig csak a 40\%-át fizeti. Ugyanakkor ez ellentétes az amerikai Portal-to-Portal Acttal is, mely szerint teljes munkabér jár a munkavállalónak az üzemben tartózkodás idejére, függetlenül attól, hogy dolgozik, ügyel vagy készenlétben áll.

A munkaszerzôdés egyoldalú végleges módosítására, a frankofón-latin államokkal ellentétben, a német munkajoghoz hasonlóan az 1992. évi Mt. sem adott lehetôséget. Viszont lehetôséget adott a munkáltatónak arra, hogy a munkavállalóját vele tartós tulajdonosi vagy gazdasági összefonódásban álló más vállalathoz kirendelje, a saját cégén belül pedig más munkakörbe, másik üzemébe, üzemrészlegébe, többnyire helyettesítésre átirányíthassa, vagy saját vállalatán belül vagy más vállalathoz kiküldhesse. Mindegyik esetében egy éven belül a 44 munkanapot, összesen pedig a 110 munkanapot nem haladhatta meg. Ezenkívül pedig lehetôséget adott a munkáltatónak arra, hogy pl. megrendeléscsökkenés okán maximum két hónapra, mintegy haszonkölcsönszerúen átengedhette más munkáltatónak feleslegessé vált munkavállalóját, megkímélve ôt az elbocsátástól. Ugyanakkor azonban azzal, hogy nem vette át a nyugat-európai államoktól azt az előírást, miszerint ha a munkaszerződésnek ez az ideiglenes módosítása az egy hónapot meghaladja, a módosításhoz a munkaügyi hivatal vagy az üzemi tanács hozzájárulása kell, ezzel Magyarországon a munkáltatók vissza is tudtak élni. Mivel az ilyen ideiglenes munkaszerzôdés-módosítást egymást követően is meg lehetett valósítani, ily módon a munkáltató a számára nemkívánatos munkavállalót felmondásra 
tudta szorítani. Ugyanakkor az is disszonáns volt, hogy ha a munkáltató a munkavállalóját átirányítással alacsonyabb fizetésú munkakörbe vagy munkahelyre küldte, csak távolléti díjat kellett a részére fizetni. Látszólag az irányelvnél ez a magyar szabály kedvezôbb volt, mivel az irányelv értelmében valamennyi itt említett szerzôdéstôl eltérô foglalkoztatás hosszabbítással kétszer 12 hónapig tarthatott, azonban a hosszabbításhoz is szükséges volt a már említett hozzájárulás, ha az az egy hónapot meghaladta. A munkaszerzốdésnek az irányelvben meghatározott, a magyar szabályozásnál jóval rugalmasabb jellege nagyobb védelmet biztosít a feleslegessé váló kényszerú munkáltatói felmondással szemben.

Áttérve a munkaviszony munkáltatói oldalról történô megszüntetésének a területére, az 1992. évi Mt. átvette a felmondásvédelemmel kapcsolatos nyugat-európai megoldásokat (felmondásindoklás, felmondási idó, végkielégítés), csupán a csoportos létszámleépítésnél jelentkezik aggályos megszorítás, amely a régi tagállamoknál az idóközi megszorításokat bevezetố irányelvi módosítások ellenére sem jellemzô. Az irányelv-módosítás előtt, ha 10 fớfoglalkoztatottat elérố üzembôl a munkáltató 5 fố elküldését tervezte, már csoportos létszámleépítésről volt szó. Az irányelv-módosítást követôen ez akként változott, hogy ha a 20 fôt meghaladó üzembôl 10 fô leépítése válhat esedékessé, ettôl kezdődően áll fenn a csoportos létszámleépítés kritériuma. Ebben az esetben a munkáltató a tervezett felmondás elôtt 30 napos tárgyalási idôvel köteles meghívni az üzemi tanácsot, ennek hiányában a vállalatnál képviselettel rendelkezó szakszervezetet, valamint a munkaügyi hivatal képviselôjét. E tárgyalási idôszak korábban az irányelv szerint 30 napos, amely bonyolultabb esetekben 30 nappal meghoszszabbítható, egyszerúbb esetekben viszont 15 napra lerövidíthetô. Németországban és Franciaországban elôírás, hogy e tárgyalásra a munkáltatónak szociális tervet kell készíteni, és csak szociálisan igazolható esetben mondhat fel a munkavállalónak. Ezt ma is alkalmazza a kontinentális nyugat-európai államok többsége, nem átvéve az IMF által javasolt gyors lebonyolítású „szenioritási” elvet, mely szerint, aki késôbb került a céghez, leépítés során elóbb megy (Birk, 1997). Az IMF és az EU ezt az elvet a közép-európai új tagállamokra akarta kiterjeszteni, végül azonban olyan kompromiszszum született, mely szerint Magyarországon is az irányelv-módosításnak megfelelôen 15 napban határozza meg a tárgyalási idôt, amely 30 napra meghosszabbítható. Ez alatt az időszak alatt a tárgyalások során arra kell törekedni, hogy minél kevesebb munkavállaló elküldésére kerüljön sor (Prugberger, 2008). Azonban - ellentétben a román Codul Munciivel (Mt.) (Kokoly, 2006:758) - a magyar szabályozás nem mondja ki, hogy ha a cég gazdaságilag helyreáll, és létszámnövelésre van szükség, az elbocsátott dolgozóinak egy éven belül az alkalmazásra elsôbbségi joguk van.

Magyarországon azonban probléma, hogy bár a munkaügyi központot a csoportos létszámleépítési tárgyalásra meg kell hívni, de azon a legritkább esetben képviselteti magát, pedig tudna segíteni azzal, hogy a régi tagállamokhoz hasonlóan - ahol kötelezó a tárgyalásokon való jelenléte -, ha a cégnek esélye van a hullámvölgyből kikerülni, a felmondások helyett rövidített munkaidôs foglalkoztatást javasoljon, kötelezettséget vállalva arra, hogy az ebból adódó bércsökkenést átmenetileg a munkanélküli-segély terhére kipótolja. Azért is jó lenne, ha a nyugat-európai megoldáshoz 
Jakab Nóra - Prugberger Tamás - Tóth Hilda: A magyar munka- és a közszolgálati...

hasonlóan a munkaügyi központ köteles lenne a tárgyalásokon képviseltetni magát, mert igen sok esetben a csoportos létszámleépítésre a munkáltató fizetésképtelensége miatti csốdeljárás kezdetekor kerül sor. Ez esetben a munkáltató gyakran többhavi bérrel adós, amelyet a felmondások idejére szóló bérekkel együtt, esetleg a végkielégítést is a nálunk nem biztosítási, hanem hitelezési alapon múködô bérgarancia-alapból lehet kifizetni, amelyet a munkáltatók a béralap meghatározott hányada szerint kötelesek havi rendszerességgel, adójellegúen a bérgarancia-alapot kezelô munkaügyi központnak befizetni. Az ilyen okból folytatott létszámleépítési tárgyalásokon a munkaügyi központ a bérgarancia-irányelvvel csak újabban összhangban álló magyar szabályozás szerint intézkedni tudna az elmaradt bérek és/ vagy esedékes bérjellegú juttatások háromhavi mérték erejéig történô kifizetése tekintetében.

Ami a magyar bérgarancia-alap magyar szabályozásának a sorsát illeti, az azt rendezó 1994: LXV. tv. sorozatos módosításokon esett át. Elôször az irányelvvel teljesen ellentétesen, a munkaügyi központ diszkrecionális jogába tartozott, hogy a bajba jutott munkáltatónak ad-e kölcsönt, vagy sem a bérek kifizetésére. Ha úgy látta, hogy a kölcsön visszafizetésére nincs esély, megtagadhatta annak kiutalását. Ez az elsô Orbán-kormány intézkedésére a 2001. évi novellával akként enyhült, hogy csak akkor tagadhatta meg a hitelkérelem folyósítását, ha a munkáltató hat hónappal korábban is kért az alapból hitelt a bérek kifizetésére, és azt nem fizette vissza. Ez sem felelt meg az irányelv tartalmának. Egy újabb módosítással, Medgyessy miniszterelnöksége idején rendezôdött a kérdés az irányelvnek megfelelóen akként, hogy az alap minden esetben köteles megadni a hitelt az elmaradt bérek és bérjellegú juttatások kifizetésére, még ha az várhatóan nem is térül vissza. Így a bérgarancia-alapról szóló magyar szabályozás már megfelel a bérgarancia-alapról szóló 80/987 EGK irányelv szempontjainak, mely szerint a ki nem fizetett bér- és bérjellegú tartozásokat a bérgarancia-alapot kezelô szerv a fizetésképtelen munkáltató helyett a biztosításból fakadó helytállási elv, vagy a hitelezési elv alapján köteles a munkáltató által ki nem fizetett béreket és bérjellegú juttatatásokat legalább háromhavi bérösszeg erejéig rendezni. Ennek érdekében, ha az adott állam nem a biztosítási, hanem a hitelezési elvet választotta, akkor is köteles a hitelt folyósítani, ha tudja is, hogy az soha nem térül vissza. Mostanra már a magyar gyakorlat is e szerint jár el, megfelelve az irányelv szempontjainak.

Még ebben a körben szükséges foglalkozni azzal, hogy a jogellenes munkáltatói felmondás szankciójaként az 1992. évi Mt. eredeti szövege előírta, hogy a munkavállalónak az elbocsátástól számítva a jogerôs visszahelyezô ítélet meghozataláig átlagkeresetet kell kifizetni, ezenkívül még a jogellenes elbocsátásból származó kárát is a munkáltató tartozik megtéríteni a munkavállalónak. Abban az esetben, ha akár a munkáltató, akár pedig a munkavállaló a visszahelyezést nem akarja, az esetleg járó végkielégítésen kívül a munkáltató 12 havi végkielégítésnek megfelelô összeggel válthatta meg a visszahelyezést. Ezt azonban az Mt.-nek egy késóbbi novellája akként módosította, hogy bírói mérlegelés állapítja meg, az 1-tôl 12 hónapig terjedó végkielégítésból hány havi jár a jogellenesen elbocsátott munkavállalónak. 
Polgári Szemle $\cdot$ 16. évfolyam 1-3. szám

\section{A közszolgálat szabályozása}

Mint már az elején szó esett róla, a közszolgálatot Magyarországon 1993 óta két, egymástól elkülönülố törvény szabályozta, és ez a helyzet ma is fennáll. A hatósági jogkört nem gyakorló közintézményeknél dolgozók mindegyike, függetlenül attól, hogy ügyintézô, ügyviteli vagy fizikai dolgozó, közalkalmazottnak minősül. Ebben a frankofón-latin hatás mutatkozik meg. Eredetileg hasonló módon mindenki, aki hatóságnál dolgozott, közalkalmazottnak számított. Az elsố Orbán-kormány azonban német-osztrák mintára csak az ügyintézóket akarta köztisztviselôi státuszban a Ktv. hatálya alatt tartani, ezért az ügykezelôket és a fizikai állományt az Mt. hatálya alá helyezte. A kormányváltás következtében azonban nem tudta ezt a tervét megvalósítani, sôt az ôt követố Medgyessy-kormány alatt az ügyviteli állomány visszakerült a Ktv. hatálya alá. A Kjt. és a Ktv. az alapstruktúráit illetôen sokban hasonlított, és még ma is hasonlít egymáshoz. A jogviszony mindkettőnél kinevezéssel jön létre. Különbség csupán az utóbbinál fennálló eskütételben, valamint a személyi feltételek különbségében van. A köztisztviselői jogviszony keletkezésénél ugyanis feltétel a nagykorúság, a magyar állampolgárság és a legalább középfokú iskolai végzettség. Ezenkívül előírás a pályázati rendszer és a gyakornoki idô letöltése, valamint a közigazgatási szakvizsga sikeres letétele. Ma már azonban a magasabb közalkalmazotti státuszoknál is hasonlóan jön létre a szolgálati jogviszony.

Eredetileg mind a kettônél - ha nem is nyugat-európai mértékben ${ }^{8}$ - relatív státuszbiztonság létezett. Ha ugyanis az intézmény vagy az ott betöltött munkakör megszúnt, mind a közalkalmazottat, mind a köztisztviselốt meg kellett kísérelni megfeleló szolgálati helyre áthelyezni, és csak végsố esetben lehetett ôt felmenteni. Ebben az esetben mind a Kjt., mind pedig a Ktv. az Mt.-nél jóval hosszabb felmentési (felmondási) idôt állapított meg, és kedvezóbb feltételek mellett nagyobb végkielégítést biztosított. Státuszbiztonságot jelentett az is, hogy a nyugat-európai államok közalkalmazottaihoz, köztisztviselőihez hasonlóan csak súlyos fegyelmi vétség esetén, fegyelmi eljárás lefolytatása mellett lehetett megszüntetni a közalkalmazotti és a közszolgálati jogviszonyt. Ugyanakkor viszont átszervezés esetén mind a két törvény lehetôvé tette a nyugat-európai közszférában teljesen ismeretlen csoportos létszámleépítést, igaz, a munkajognál a közalkalmazottakra, köztisztviselôkre sokkal kedvezóbb feltételekkel, mivel már 5 fó leépítésénél a munkajogi csoportos létszámleépítésnél bemutatott elôírásokat kellett alkalmazni. Kritikaként kell azonban megemlíteni, hogy mind a két törvény esetében a vezetôi kinevezés bármikor indokolás nélkül visszavonható volt, és csak a közalkalmazott kívánságára kellett utólag megindokolni. Ez könnyen önkényeskedéshez és státuszbizonytalansághoz vezethetett, mivel ha az elmozdított vezetôt hely hiányában nem lehetett besorolni és áthelyezni, kikerült a közszférából.

A különbségeket nézve, a közalkalmazotti szférában a munkaidô és a túlmunka szabályai a pótlékokkal együtt megegyezett az Mt. előírásaival. Hasonló helyzet állt fenn a pihenôiidôk és a szabadság vonatkozásában is. Ezzel szemben a Ktv. a napi munkaidô kezdetét és végét szigorúan meghatározta, a túlmunkát azonban sem pótlékkal, sem a túlmunkával arányos szabadidôvel nem honorálta. A Ktv. évente néhány szabadnapot 
Jakab Nóra - Prugberger Tamás - Tóth Hilda: A magyar munka- és a közszolgálati...

biztosított csupán a „rekreációs” szabadsággal együtt, azonban utóbb mind a kettôt eltörölték. Az elsố Orbán-kormány átmeneti jelleggel bevezette az ún. „fóhivatalnoki” rendszert, amely stábhoz tartozó köztisztviselók mint bizalmi emberek, az átlagosnál nagyobb fizetéssel, szükség szerint bárhová helyezhetôk voltak. Ezt az intézményt azonban az elsố Orbán-kormányt felváltó Medgyessy-kormány felszámolta.

A köztisztviselói kart érintô szabadságolási rendszer a besorolástól függött. Minthogy a köztisztviselóknek kétféle besorolási rendszere létezett, melyek közül egyik a beosztott köztisztviselókre, a másik pedig a vezetô köztisztviselókre vonatkozott, ennek megfelelôen a beosztott és a vezetô köztisztviselók szabadsága is e két besorolási osztály szerint alakult. A pótszabadságok mértékét ugyanis a beosztott köztisztviselók esetében a besorolási cím, míg a vezetôknél a vezetôi szint határozta meg. Mindezek alapjaiban máig sem változtak.

Bár mind a közalkalmazotti, mind a köztisztviselôi szférában a besorolás és ennek megfelelôen a fizetés elsôdlegesen a képzettség, a képesítés, vagyis az iskolai végzettség fokától függ, másodlagosan fontos a letöltött közszolgálati idô. Ettôl függetlenül azonban a besorolási rendszer egészen más a közalkalmazotti és a köztisztviselôi szférában. Az elóbbi némileg a frankofón-latin és az osztrák rendszerre emlékeztet. Az osztrák rendszerhez hasonlóan (Bundesgehaltgesetz) a besorolási (fizetési) osztályokat egyre magasabb képzettségi szintek szerint, ábécésorrendben határozzák meg, és minden osztálynál 17-17 besorolási (fizetési) fokozat van a letöltött szolgálati idő függvényében (Veszprémi, 2012a, 3. fejezet; Prugberger, 2013:240-245). Ezzel szemben a Ktv. esetében a német megoldáshoz hasonlóan (Bundes- und Landesbesoldungsgesetz), az ügyintézó beosztott köztisztviselôknek aszerint, hogy felsô- vagy középfokú végzettséggel rendelkeznek, két besorolási osztályuk van, 11-11 címmel megjelölt besorolási és egyúttal fizetési fokozattal (Peine-Heinlein, 1999:42-60, 105-117). A besorolási fokozatokat és az azokon belüli alfokozatokat a szolgálati idô függvényében határozták meg. Az ügykezelői besorolási osztályon belül 7 fokozat van. Bár lényeges különbség van a két besorolási rendszer között, össze lehetne hangolni a kettôt. Mind a hatóságoknál, mind pedig a nem hatósági közintézményeknél a köztisztviselôi besorolási rendszert lehetne alkalmazni az ügyintézôi szférában, az ügykezelói és a fizikai állománynál pedig a közalkalmazotti besorolási rendszert. A vezetôi besorolási rendszer pedig lényegében hasonló mind a kettônél. Csupán a köztisztviselői besorolást kellene kissé egyszerúsíteni. Így elhárulna az akadály a két szféra egységesítése elől. ${ }^{9}$

\section{A RENDSZERVÁLTÁST KÖVETÓ MÁSODIK MUNKA- ÉS KÖZSZOLGÁLATI KODIFIKÁGIÓ SORSA ÉS ÉRTÉKELÉSE}

\section{A 2012. évi Munka törvénykönyve}

2008-2009-ben a világon az utóbbi 80 év legsúlyosabb pénzügyi-gazdasági válsága alakult ki, amelynek az egyik következménye a munkanélküliség emelkedése volt. Már a válságot megelőzóen az EU foglalkoztatáspolitikai szakirodalmában megjelent az ún. „rugalmas biztonság” ${ }^{10}$ elnevezésú program, amely magában foglalja a rugalmas és meg- 
bízható szerzôdéses rendelkezések szükségességét, az egész életen át tartó tanulást, az aktív munkaerópiaci politikát, a rugalmasabb szociális biztonsági rendszerek megteremtésének szükségességét mind a nemzetközi, mind a nemzeti szabályokban (Tóth, 2017; Jakab, 2017). Ez a program indította útjára azt a vitát, amelynek a középpontjában a munkajog fejlódésének kérdése állt, és ehhez kapcsolódik az ún. Zöld Könyv megszületése (EC, 2006). Ez nyilvános vita indítása volt arról, hogyan lehetne a fenntartható növekedést, a több és jobb munkahelyteremtést elérni az EU-ban a munkajog fejlesztésével. A tanulmányt 2006-ban publikálták, és már ekkor a 21. század kihívásairól is szólt.

Az új Munka törvénykönyve koncepciójának kidolgozásakor az egyik alapvetô cél volt a Zöld Könyvben megfogalmazott ajánlások beemelése a belsó jogrendbe, a rugalmas foglalkoztatás feltételeinek a megteremtésével, a munkavállalók szociális biztonságának megórzése mellett. Az új Munka törvénykönyve tehát figyelembe vette a nemzetközi társadalmi és gazdasági változásokat, és döntôen a diszpozitivitás irányába terelte a munkajogi szabályozást. Ezzel a munkáltató és a munkavállaló, valamint a szakszervezet és a munkáltató közötti megállapodásoknak ad nagyobb teret a munkaviszony tartalmának kialakításakor, és háttérbe szorul az állam beavatkozó szerepe. Általánosságban megállapítható, hogy a kialakult gazdasági válság következményeinek egyfajta kezelésére megfeleló volt a jogalkotó szándéka, azonban a szociális partnerek a diszpozitivitás előtérbe helyezésében a munkavállalói jogok és kollektív munkaügyi jogok csorbítását látják.

Az új Mt. jelentős változásai közé sorolható, hogy a 2013-ban hatályba lépett Polgári törvénykönyv rendelkezései egyértelmúen megjelennek a munkajogi szabályozásban, így különösen az általános rendelkezések körében és a munkajogi kártérítési felelôsség szabályaiban látszik.

Az új jogszabály a felek megállapodásainak ad nagyobb teret, és az individuális részben a munkaviszony tartalmára nézve nagy részben keretszabályokat tartalmaz azzal, hogy a felek e szabályoktól a munkaszerződésben vagy a kollektív szerződésben eltérhetnek. Elsố látszatra ez a megoldás teljesen korrektnek túnik. Behatóbban megvizsgálva azonban, az új Mt.-nek ez a megoldása problematikus, mivel a munkáltató az erôsebb fél, akinek a munkavállaló egzisztenciálisan is kiszolgáltatott. Ezért minden ilyen megállapodásban a munkáltatói akarat érvényesül, vagy ha a munkavállaló vonakodik a munkáltató ajánlatát elfogadni, a munkáltató retorzióval élhet vele szemben. Nem véletlen, hogy a frankofón-latin államok munka törvénykönyvei ma is tele vannak a munkavállalók szociális és egzisztenciális helyzetét védô előírásokkal, amelyeket a germán jogrendszerekben kodifikált munkatörvényi hiány miatt külön törvények rendeznek (Prugberger-Nádas, 2014:48-50).

Emiatt a munkajogon belül a munkavállalói jogalanyiság központi terület. Ugyanis a jogalkotó a munkavégzôk jogviszonyai közül nem mindegyik tevékenységet folytatóra terjeszti ki a szociális és egzisztenciális védelmet jelentô munkajogi szabályozást, és így a munkajogi védelmi rendszer hatályát. A tartós vállalkozási és megbízási szerzôdés igen sok tekintetben hasonlít a munka-, illetve a szolgálati viszonyhoz, mégsem terjeszti ki rájuk a munkajoggal kapcsolatos szociális és egzisztenciális védelmet, mivel önálló cégtulajdonosi helyzetük önmagában is védelmet biztosít a tartósan foglalkoztatott 
Jakab Nóra - Prugberger Tamás - Tóth Hilda: A magyar munka- és a közszolgálati...

vállalkozók és megbízási tevékenységet folytatók számára. Mostanában viszont egészen új jövedelemforrást jelentô foglalkoztatási formák jönnek létre, ezért alapvetôen jogpolitikai kérdés annak eldöntése, hogy kikre terjed ki a munkajogi szabályozás személyi hatálya. Ezt a jogpolitikai döntést ugyanakkor gazdasági és társadalmi változások/ elvárások kényszerítik ki, és a közeli jövôben Magyarországon is égetô kérdésként jelentkezik majd a jövedelemforrást jelentô számtalan atipikus kiszolgálói tevékenység megjelenésével, mint amilyen pl. az Uber és a hozzá hasonló szolgáltatásnyújtások. Kérdés, hogy közülük melyikre kell kiterjeszteni a szociális és egzisztenciális védôernyốt biztosító munkavállalói jogalanyiságot.

Munkavállalói jogalanyiság alatt az általános és konkrét munkavállalói képesség értendô. Általános munkavállalói képesség a törvényi feltételeknek megfelelô képességet jelenti, a konkrét pedig az adott munkakör betöltésére vonatkozó képességet. Az általános és konkrét munkavállalói képesség az intellektuális és pszichoszociális fogyatékossággal élô személyek és a megváltozott munkaképességú személyek szempontjából bír különös jelentôséggel. Éppen ezért a munkavállalói jogalanyiságnak létezik egy tágabb koncepciója, amely a fogyatékossággal éló emberek foglalkoztatására vonatkozik. Ez a koncepció környezeti és személyes tényezôk összessége, ugyanis nemcsak az egyén egészségi állapota és képességei határozzák meg a foglalkoztatás sikerét, hanem a fogyatékosság társadalmi elfogadottsága, a gazdasági és munkaerôpiaci körülmények, a felnôttvédelmi szabályozás, az oktatási és képzési rendszer fejlettsége és befogadóképessége is. Abban az esetben, ha a cél minél több ember munkaerôpiacra integrálása, ideértve a fogyatékossággal élô embereket is, a jogalkotónak egy holisztikus szemléletet kell alkalmaznia, s be kell látnia, hogy az integráció nemcsak munkajogi, hanem tágabb értelemben vett foglalkoztatási, rehabilitációs, oktatási és felnôttvédelmi szabályozási kérdés is.

Emellett a munkavállalói jogalanyiság dinamikusan változik. A dinamikája történetiségében, a gazdasági és társadalmi eseményekkel összefüggésben határozható meg. A dinamikát a munkajogi szabályozás személyi körökre való kiterjesztése, lényegében az atipikus munkaviszonnyá minôsítés, vagy e minôsítés megtagadása, azaz bizonyos munkavégzôk munkajogi szabályozásból való kirekesztése adja.

A 21. század gazdasági környezetében megjelenô foglalkoztatási viszonyok hatással vannak a munkajog személyi hatályára, a munkavállalói jogalanyiságra, azaz arra, hogy kit is tekinthetünk munkavállalónak, és melyek a függó munkavégzés határai. A kiterjesztésben Európában szerepe volt és van a bírói jogalkalmazásnak, jogelméleti gondolkodóknak, a jogalkotásnak és a kollektív tárgyalásoknak. A függó munkavégzés határai kijelölésében a következô utak határozhatók meg az európai munkajog rendszerében: az elsố a munkavállaló fogalmának kiterjesztése, a második a munkát végzôk harmadik típusának megalkotása (tertium genus), a harmadik a munkát végzốk egyfajta közös jogának megalkotása és a különbözó szintú jogok bizonyos széles kategóriákra való kiterjesztése, a negyedik a kirekesztés. Egyértelmú, hogy a munkát végzôk nem kezelhetôk egységes masszaként. A jogpolitika válasza erre az volt, hogy szükséges a munkavállaló és vállalkozó között egy közbülsô fogalom megalkotása, és ehhez megfelelố munka- és szociális jogi védelmet kapcsolni. 
A munkajogban az egyéni önrendelkezés a munkaszerződés, illetve a munkajogviszony két alanyi pozíciójának akarata által realizálódik, ezért a kötelem alanyi körének meghatározása alapvetố jelentôségú, azaz a munkajogtudomány egyik kardinális problémájává vált. A munkáltató-munkavállaló fogalmak egymással korrelatív kapcsolatban állnak (Prugberger-Nádas, 2014:249, 253, 258; Kiss, 2005:104). Az irodalomban van olyan felfogás, amely a munkavállaló fogalmán keresztül határozza meg a munkajogviszony megkülönböztetố ismérveit (a munkajog a munkavállalók Sonderrechtje) (Kiss, 2005:116). Mindezt figyelembe véve munkavállaló az, aki más számára munkatevékenységet végez. Ezzel tudunk különbséget tenni a munkavállaló és az önálló munkavégzô között. ${ }^{11}$ Ez a fogalom a munkavégzésre helyezi a hangsúlyt, azaz a munkavégzési képességre. Ebben a megállapításban nincs szerepe a cselekvôképességnek.

A korábbi Mt. 72. §-a szerint a 16. életévét betöltött kiskorú és a korlátozottan jogképes személy törvényes képviselőjének hozzájárulása nélkül is létesíthetett munkaviszonyt. Ez alapján a munkavállalói minôség feltétele az életkor betöltése mellett a legalább korlátozottan cselekvôképesség megléte volt, ami összhangban állt a Polgári törvénykönyvről szóló 1959. évi IV. törvénnyel. Ugyanakkor a régi Mt. 72. §-a és a fogyatékos személyek jogairól és esélyegyenlőségük biztosításáról szóló 1998. évi XXVI. törvény (a továbbiakban Fot.) között ellentmondás állt fenn. A Fot. 15. és 16. szakaszai szerint a fogyatékos személy lehetôség szerint integrált, ennek hiányában pedig védett foglalkoztatásra jogosult.

Integrált foglalkoztatás esetén a munkáltató köteles biztosítani a munkavégzéshez szükséges mértékben a munkahelyi környezet, így különösen a munkaeszközök, berendezések megfelelő átalakítását, amihez a központi költségvetésbool támogatást igényelhet. Ezenkívül a felvételi eljárás során a munkáltató a fogyatékos személy munkához jutásának elôsegítése érdekében minden vonatkozásban köteles biztosítani az egyenlô eséllyel hozzáférhetô környezetet. A munkáltatót ezek a kötelezettségek akkor terhelik, ha a megüresedett álláshelyet nyilvánosan meghirdette, és az álláshelyre a fogyatékos személy oly módon jelentkezett, hogy jelezte a meghallgatáshoz szükséges speciális igényeit, valamint azok biztosítása a munkáltató számára nem jelent aránytalanul nagy terhet. Aránytalanul nagy tehernek minôsül az, ha a kötelezettség teljesítése a munkáltató múködését ellehetetleníti. Ha a fogyatékos személy foglalkoztatása ilyen módon az integrált foglalkoztatás keretében nem valósítható meg, úgy számára a munkához való jogát lehetôség szerint akkor is biztosítani kell. A megváltozott munkaképességú munkavállalókat foglalkoztató akkreditált munkáltatókat és a szociális foglalkoztatást végzô foglalkoztatókat a központi költségvetés - jogszabályban meghatározottak szerint - támogatásban részesíti.

Mindebból kitúnik, hogy a korábbi Mt. csak a korlátozottan cselekvóképes személyek számára tette lehetôvé a munkaviszonyban való megjelenést. A cselekvôképességgel nem rendelkezô fogyatékossággal élô emberek munkához való jogáról eredetileg a korábbi Mt. nem beszélt. Csak a Fot. tartalmazta a foglalkoztatás és a munkavégzés során alkalmazott egyenlô bánásmód általános keretei létrehozásának való megfelelés szabályait egészen addig, míg a korábbi Mt. 5. §-ába az egyenlő bánásmód betartásának általános kötelezettsége, megsértése orvoslásának elóírásával együtt. Ez a kötele- 
Jakab Nóra - Prugberger Tamás - Tóth Hilda: A magyar munka- és a közszolgálati...

zettség változatlanul átkerült az új Mt. 12. szakaszába is. Ennélfogva a munkáltató az egyenló eséllyel hozzáférhetô környezetet jelenleg is köteles biztosítani a fogyatékos személy foglalkoztatása esetén. A módosítás célja az volt, hogy ez a kötelezettség a munkavállalást megelôzô felvételi eljárás során is fennálljon. Az egyenlô bánásmódnak a fogyatékos személyekre is kiható konkrét előírásait az esélyegyenlőség előmozdításáról szóló 2003. évi CXXV. törvény (Ebktv.) tartalmazza.

Az új Mt. megalkotásáig lényegében a Fot. és az Ebktv. ellensúlyozta a munkavállalói jogalanyiságnak a cselekvôképességhez történt feltételhez kötését, ami azért volt ellentmondásos, mert más helyen a szükséglettôl vezérelve szólt a cselekvóképtelen személyek munkaviszonyban történố munkavégzésérôl, ahol a munkaszerzôdést helyettük a törvényes képviselő köti meg. Ha viszont a cselekvôképtelen személynek nincs törvényes képviselôje, nem lehetett munkavállalói jogalanyisága. Ezt az ellentmondást oldotta fel az új Mt. azzal, hogy szakított a régi Mt.-nek a munkavállalói jogalanyiság cselekvơképességhez kötésével, és csak annyit mond ki a 34. szakaszában, hogy munkavállaló az a természetes személy, aki munkaszerződés alapján munkát végez. Ezáltal az új Mt. a cselekvôképteleneket is potencionálisan besorolta a munkavállalók kategóriájába. Emellett az új Ptk.-ra figyelemmel, az új Mt.-be is beiktatták a relatív cselekvôképesség kategóriáját, hogy ha a nem abszolút korlátozottan cselekvôképes, gondnokság alatt álló személy abban a körben, amelyben belátási képessége teljes, törvényes képviselőjének hozzájárulása nélkül is megkötheti a munkaszerzôdést.

Mindezek alapján a személyi és gazdasági függést magában foglaló munkavégzés az, amely a munkajog keretein belül marad. Ennek figyelembevételével kerültek az új Mt.-be atipikus munkaviszonyként a jövedelemforrást jelentô tevékenységek közül csak azok, ahol a munkáltatótól, illetve a megbízótól fennálló személyi függés valamilyen formában fennáll, mint pl. a távmunka és a e-dolgozói jogviszony esetében.

Míg a munkavállalói jogalanyiságnál az új Mt. viszonylag széles körben figyelembe vette a munkavállalói érdekeket, ez nem mondható el a munkajogviszony tartalmát érintô kérdések rendezésére. A munkajogviszony tartalmának két leglényegesebb területét, a munkaidôt, a pihenőidôt és a szabadságot, valamint a munkabért, azon belül a pótlékokat is érintve ugyanis az új Mt. a korábbihoz képest jelentôsen lefaragta a munkavállalókat megilletố jogokat. Ami a munkaidôt illeti, a rendes munkaidô az irányelvvel egyezốen 48 óránál több nem lehet. Ugyanakkor az új Mt. lehetôvé teszi, hogy a munkavállaló heti 60 órát nem meghaladó túlmunkát a munkáltatóval külön megállapodva vállalhasson. E vállalás azonban legfeljebb 6 hónapra szólhat, ami viszont meghosszabbítható. A nyugat-európai munkajogokban a munkavállaló e vállalását bármikor felmondhatja. A magyar Mt. azonban ilyen lehetóséget nem tartalmaz. A korábbi Mt.-ben a nyugat-európai gyakorlatnak megfelelôen a túlmunka után fôszabályként pótlék jár, és csak akkor szabadidô, ha ezt a munkavállaló kérte. Az új Mt. szerint a túlmunka elszámolása pótlékkal vagy szabadidővel történjen, a munkáltató és a munkavállaló megállapodásán múlik. E megállapodásnál is, ami a már tárgyaltak értelmében, a munkáltatói akarat érvényesül.

A túlmunkát elvileg a következô hónap végéig kell elszámolni, azonban lehetôség nyílik egy hosszabb idôintervallumban, az ún. „referencia-idôszakon” belül, átla- 
golás mellett elszámolni. Ennek hossza a munkaidőrool és a pihenőidôrool, valamint a szabadságról szóló irányelv és a magyar Mt. szerint is szerint 6 hónap, idény- és készenléti munka esetén pedig 12 hónap lehet. Ez alatt az idôszak alatt kell kiegyenlítôdnie a rugalmasan alkalmazott munkaidônek, ami ha átlagolva a heti 40 órát meghaladja, pótlék vagy szabadidô jár az utólagos elszámolás mellett. Ágazati kollektív szerzôdéses felhatalmazással egyes nyugat-európai államokban fel lehet vinni 12 hónapra, sốt azt meghaladó idôre a referencia-idôszakot. Magyarországon viszont, az Mt.-módosítással ezt egyedülálló módon, a 2018. évi december végi Mt. novella 3 éves idôtartamra tágította. Bár e hosszabbításra a munkáltató és a munkavállaló megállapodása alapján kerülhet sor, azonban hiányzik a munkáltatói nyomás féken tartását biztosító ágazati kollektív szerzôdés szükségessége (Prugberger-Tóth, 2019). Erre azért is szükség lenne, mert a munkaidókeretnek, másképpen szólva a referencia-idôszaknak e 3 évre történố meghosszabbításának a lehetôségében benne rejlik, hogy a túlórák után járó pótlékokat 3 évenként számolja el és fizeti ki a munkáltató. Ilyen hosszú idôszakban pedig fennáll akár a munkáltató csôdbe jutásának és felszámolásának az eshetôsége, benne annak a veszélye, hogy vagyon hiányában egyszerúsített felszámolásra kerül sor, és a munkavállalók nem kapják meg a teljesített túlóráik után járó pótlékukat, a bérgarancia-alap pedig csak korlátozott mértékben rendezi a munkavállalók irányában fennálló munkáltatói bértartozásokat. Emellett az is tény, hogy míg Magyarországon általában a törvényileg fôszabályként engedélyezett 4 havi munkakeret alkalmazása a szokásos, azt azonban több vállalat a törvény előírásainak megfelelóen kollektív szerzôdéssel 6 hónapra felemeli, addig az EU régi tagállamaiban a referencia-idôszak általában 2-4 hétnél nem több (PrugbergerTóth, 2019).

Ami a múszakokat illeti, az irányelv ez alatt az éjszakai múszakot érti, amelynél azok részére, akik állandóan éjszaka dolgoznak, és ezért a szervezetük bioritmusa erre áll be, kevesebb összegú múszakpótlékot kapnak a nemzetközileg kialakult munkajogi szabályozás vagy a gyakorlat szerint. A pótlék esetükben általában 15\%. Ezt alkalmazza a magyar gyakorlat is. Váltott múszakban történô dolgozás esetén az éjszakai munkavégzést a magyar jog is a külföldihez hasonlóan 30\%-kal honorálja, a munkavégzés napszakának hetenként történó változásából eredó, nagyobb szervezeti megterhelés miatt. Ezt a korábbi jogunk a múszakváltásos munkavégzés esetén a délutáni múszaknál is figyelembe vette azzal, hogy a délutáni múszaknál $20 \%$ pótlékkal emelte meg az alapmunkabért. Az új Mt. ezen akként változtatott, hogy megszüntette a délutáni múszakpótlékot, helyette azonban este 6 órától másnap reggel 6 óráig tartó 15\%-os mértékú múszakpótlékot vezetett be, amelynek értelmében aki ez alatt az idôszak alatt akár csak egy órát is dolgozik, $15 \%$ pótlék felvételére jogosult. ${ }^{12}$

A munkabérezésnél is változások történtek. Pozitív változás, hogy a minimálbér kiegészült a garantált minimumbérrel, amely magasabb a minimálbérnél, és a középfokú iskolai végzettségúeknél és annál magasabb képzettségúeknél kell azt alkalmazni. Negatív változás viszont, hogy a kormány mind az alapbért, mind a garantált bérminimumot a szociális (koalíciós) partnerek bevonása és velük való érdekegyeztetés nélkül, egymaga állapítja meg, és csak az inflációt veszi figyelembe, a fogyasztói kosarat 
Jakab Nóra - Prugberger Tamás - Tóth Hilda: A magyar munka- és a közszolgálati...

viszont nem. Az sem mondható pozitív változtatásnak, hogy az új Mt.-ból kikerült a természetbeni munkadíjazás, illetve azt cafeteriaként alkalmazta tovább.

Még két munkajogi intézményrôl szükséges szót ejteni, melyek közül az egyik a munkaviszony-módosítás, amit a germán jogrendszerhez tartozó munkajogi elóírásokhoz hasonlóan, a magyar Mt. szerint is fôszabályként közös megegyezéssel lehet végrehajtani. Ideiglenes jelleggel azonban a munkáltató módosíthatja a munkaszerzódést a saját cégén belül másik munkakörbe vagy munkahelyre történô átirányítással, más munkáltatóhoz történố kirendeléssel, kiküldéssel, valamint haszonkölcsönbe adással. Errôl az Mt. 53. §-ában szabályozott, szerzôdéstôl eltérô foglalkoztatás szól, amely szerint a munkavállalót egy éven belül csak egy alkalommal lehet a szerzódéstôl eltérô módon foglalkoztatni. Ez alapvetóen kedvezóbb a munkavállalók számára, mint a korábbi Mt. szabálya, amely egy éven belül lehetôvé tette mindegyiknek évi 44 napot el nem érô alkalmazását azzal, hogy alkalmazásuk összességében nem haladhatja meg a 110 munkanapot. Ugyanakkor azonban a korábbi Mt.-hez hasonlóan a jelenlegi sem szól a kiküldési irányelvnek arról a lehetôségérôl, hogy a munkavállaló átirányítására, kirendelésére, haszonkölcsönbe adására maximum egyéves időtartamra lehetôség nyílhat, ami meghosszabbítható, szintén legfeljebb egyéves időtartamra. Ezzel jó lenne kiegészíteni az Mt.-t az olyan esetekre, amikor megrendelési pangás van, mert ilyen módon a munkaviszony-megszüntetések elkerülhetôk lennének. Ezt a kiegészítést öszsze lehetne kapcsolni a külföldre történő munkaszervezéssel, amelynek az új Mt.-ben lefektetett szabályai azért hiányosak, mert az itt említett hosszabbítási lehetôséggel megfejelt egyéves korlátjáról nem tesz említést. ${ }^{13}$ A munkaszerzôdés módosításának másik esete a munkáltatói jogutódlás. Ennek szabályai a korábbi Mt.-hez viszonyítva nem változtak, és megfelelnek a munkáltatói jogutódlásról szóló 2001/23. számú EK irányelvnek és a munkavállalók méltányos érdekeinek.

A munkáltatót a munkavállalóval szemben terhelő kártérítési felelôsség szabályait az új Mt. módosította, és részben új alapokra helyezte. Bevezette a munkajogban a polgári jogi felelősség rendszerébe beiktatott kimentés intézményét, ezen belül is az elôreláthatósági klauzulát, amely a munkáltató részbeni mentesülését eredményezheti a kár megtérítése alól, ha a károkozás idején nem volt előre látható a kár. A másik szabály szintén a munkáltató kártérítési felelôsségének a szúkítésére ad lehetôséget azzal, hogy az „ellenôrzési kör” intézményét vezeti be a „múködési kör” helyett. Ez utóbbi jóval tágabb és objektív kategória, a szabályozás lényege szerint a munkáltató mentesül a felelősség alól, ha a kárt az ellenôrzési körön kívül esố körülmény okozta. Ezzel szemben az 1992. évi Mt. a munkáltató kártérítési felelôsségét - különösen munkabaleset esetén - a veszélyes üzemi felelósség analógiája alapján rendezte, ahol sokkal kisebb volt a lehetôség a kimentésre, mint a jelenlegi Mt. alapján, ahol a munkáltató az ellenôrzési körén való kívüliség, valamint a baleset bekövetkezését érintô előreláthatóság hiányával könnyebben ki tudja magát menteni a felelôsség alól. A veszélyes üzemi felelôsség analógiájára történô szigorúbb felelősség és kimentési lehetôség helytállóbb volt a mostaninál, mivel az üzem múködése a munkáltató kockázata. Ezt alátámasztja az is, hogy a múködésból adódó nyereség is az övé. Ezért megalapozatlan minden olyan munkáltatói oldalon jelentkezó törekvés, amely meg akarja 
osztani az üzem múködésével járó kockázatot a munkavállalókkal. Ezenkívül ez az új szabály diszkriminatívan is hátrányos a munkavállalókra nézve. Ugyanis ha pl. egy üzemi robbanás következik be, és a munkavállalókon kívül mások is megsérülnek, a munkáltató irányukban a veszélyes üzemi felelôsség szigorúbb szabályai szerint felel, mint a munkavállalói irányában, ahol - miként már szóltunk róla - könnyebben kimentheti magát (Prugberger, 2014b:145-150). Nem véletlen, hogy e fonákság kiküszöbölése érdekében a bírói gyakorlat a Kúria iránymutatása alapján a korábbi jogi elốrásokra áthangolva alkalmazza (Sipka, 2015, V. fejezet).

A munkavállalót a munkáltató irányában terhelô kártérítési felelôsség elôírásai kisebb mértékben módosultak, ezek viszont a munkavállaló hátrányára. A felróhatóság polgári jogi kártérítési fogalmának bevezetése helytálló, ahogy az is, hogy azon belül megkülönböztetik a kártérítési összeg mérséklésére kihatóan a vétkesség különbözô alakzatait. Az viszont indokolatlanul terhes a munkavállalóra, hogy ha az átlagosnál súlyosabb gondatlansággal okoz kárt a munkáltatónak, elvileg a teljes kár megtérítésére kötelezhetô. Ilyen esetekben ugyanis a nyugat-európai jogok szintén mérséklik a kártérítés összegét, ahol nemcsak a munkavállaló esetében a többórás, monoton munkafolyamat ismétlődéséból eredó károkozási kockázatnövekedést lenne szükséges figyelembe venni (Eörsi, 1961:16; Nagy, 1964:15-16), hanem azt is, hogy az üzemen belüli munkavégzésnél a munkáltató a munkafelügyeleti tevékenysége során megelôzheti vagy enyhítheti a károkozás negatív hatásait (Deli, 2013).

A jogellenes munkaviszony megszüntetése jogkövetkezményeinek rendszere is jelentôs átalakításon ment keresztül. Az egyik változás, hogy a munkavállaló csak rendkívül kirívó jogsértések esetén - öt esetben - kérheti a jogellenes megszüntetéskor a munkaviszony helyreállítását (Gyulavári, 2015:227). A jogellenes megszüntetés esetén a munkavállaló a régi uniós tagállamok többségének elóírásaival ellentétben visszahelyezést nem, hanem csak kártérítést követelhet, amely sokkal csekélyebb mértékú kártalanítást jelent, mint korábban (Prugberger, 2013). Kártérítés esetén elmaradt jövedelmet érvényesíthet, azonban a kártérítés összege korlátozott, nem haladhatja meg a 12 havi távolléti díjat. Az új szabályok a Ptk. kárenyhítésre vonatkozó rendelkezéseit is átvették, amelynek értelmében a munkavállaló köteles a munkaviszonya megszüntetését követôen új munkahelyet keresni, és azt igazolnia is kell a bíróságon. Ezzel szemben a régi tagállamoknál a munkáltató a visszahelyezésen kívül a munkavállaló teljes kárát köteles megtéríteni. Sôt, az Egyesült Királyság jogát átvéve, több észak-európai államban a munkaviszonynak a munkáltató által jogellenesen történó megszüntetése esetén „ex lege” meghatározott összegú báziskártérítési átalány jár a munkavállalónak, ha pedig a munkavállalót ért kár ennél nagyobb, akkor a báziskártérítés összegét meghaladó kompenzációs kárát is érvényesítheti. Ez esetben azonban a bizonyítási teher a munkavállaló oldalán van (Prugberger, 2013).

A munkaügyi kapcsolatok területén a kollektív szerzódésekkel kapcsolatos lényeges változás, hogy a törvény a legcsekélyebb mértékben korlátozza a felek kollektívszerzódés-kötését. A kollektív szerzôdés megkötésére vonatkozóan az új törvény lényegesen módosította a szabályokat, így a kollektív szerzôdést már az a szakszervezet megkötheti, amelynek a taglétszáma eléri a munkáltatónál munkaviszonyban álló munkaválla- 
Jakab Nóra - Prugberger Tamás - Tóth Hilda: A magyar munka- és a közszolgálati...

lók 10\%-ot. Ez a szabály abszolút antidemokratikus, mert ha a cégnél nem múködik még más szakszervezet, így egy kisebbség a saját akaratát rá tudja kényszeríteni a munkavállalók többségére, akiknek a sérelmére a kollektív szerzôdést megkötô munkáltató sikeresen össze tud játszani a szakszervezettel. Korábban a szakszervezeteknek az üzemitanács-választásokon elért eredményessége volt a szerződéskötési képesség mércéje.

Jogdogmatikailag és jogrendszertanilag teljesen megalapozatlan, hogy az üzemi tanácsot az új Mt. a szakszervezet elé helyezte. Ebben az USA megoldásának követése játszott közre, ahol a munkáltatók szívesebben tárgyalnak közvetlenül a munkavállalókkal, és kötnek velük „win-win” megállapodásokat, mint az érdekérvényesítést keményebben képviselô szakszervezetekkel. Újabban üzemi tanácsi képzôdmények megjelentek az USA egyes államaiban is, de csak véleménynyilvánítási és konzultációs joguk van, a nyugat-európai államok többségéhez hasonló együttdöntési joguk azonban nincs (Hennsler-Frik, 2003:557-558). Valószínúleg e minta leképezése alapján vált teljesen szúkké és formálissá az új magyar Mt.-ben az üzemi tanács együttdöntési joga.

Ami az érdekegyeztetés jogát és a szociális partnereknek az állammal történó háromoldalú kollektívszerzôdés-kötési lehetôségét illeti, az teljesen átalakult. A 2011. évi XCIII. tv. teljesen átalakította a Nemzeti Munkatanácsot, illetve az OÉT-t. Kibôvítette Nemzeti Gazdasági és Társadalmi Tanáccsá, és konzultatív véleményezô intézménnyé tette, amelynek keretében országos általános kollektív szerzôdés nem köthetô. Ennélfogva csak a már bemutatott ágazati és területi érdekegyeztetés múködik, az ágazati párbeszédbizottságok részvételével. Ezért ágazati kollektív szerzôdés létezik. A vállalati kollektívszerzôdés-kötés pedig elfogadhatatlanul akként módosult, hogy a szakszervezet tízszázalékos reprezentativitás mellett egyedül is köthet a vállalat vezetésével kollektív szerzốdést, a szakszervezethez nem csatlakozott munkavállalókra is kihatással. ${ }^{14}$ A miniszteri indoklás szerint a jogalkotó e módosításoktól azt reméli, hogy jelentôsen növeli az érdekképviseletek aktivitását a munka világának alakításában, egyúttal viszszaszorítja az indokolatlan állami beavatkozást, illetve azt piackonform megoldások alkalmazására korlátozza. Ezzel viszont közben kiszolgáltatja óket a munkáltatóknak.

\section{A közszféra jogviszonyainak szabályozása 2010 után}

A 2010. tavaszi kormányváltást követôen a baloldali-liberális Bajnai-kormányt felváltó új polgári kormány (2010-2014) megalkotta a kormánytisztviselők jogállásáról szóló 2010. évi LVIII. tv.-t. Ezzel lényegében kiüresítette az 1992-es köztisztviselôi törvényt, amely ezt követôen csak az önkormányzatoknál foglalkoztatott köztisztviselôkre vonatkozott. Ezt követôen, alig több mint egy év múlva, 2012. március 1-jétôl mind a kormánytisztviselôi törvény, mind a köztisztviselôi törvény hatályon kívül helyezésével párhuzamosan elkészült és hatályba lépett a közszolgálati tisztviselôkrôl szóló törvény (2011:CXCIX. tv., Kttv.). Az új törvény a kormánytisztviselôi törvény beemelésével magában foglalta a kormánytisztviselők, valamint a kormánytól független, „autonóm” hivatalok (országgyúlési, köztársasági elnöki stb.) köztisztviselóinek, valamint az önkormányzati köztisztviselók (megyei és települési) jogállását, jogait és kötelezettségeit. 
Összehasonlítva a nyugat-európai államok köztisztviselôi (közhivatalnoki) törvényeivel, azok a problematikus eltérések, amelyekrôl a Ktv. kapcsán már szó esett, továbbra is fennmaradtak. Sót a köztisztviselók státuszbiztonsága tovább gyengült, és a felettesüktôl való függôségük tovább erôsödött. Az új Kttv. ugyanis előírta, hogy a köztisztviselô lojális magatartást köteles tanúsítani felettesével szemben, ugyanakkor viszont a felettes „bizalomvesztés” címén felmentheti a köztisztviselőt, ami a konstruktív kritika elfojtásához és kontraszelekcióhoz vezethet. Gyengíti a köztisztviselői státuszbiztonságot az is, hogy a Kttv.-ból kikerült az a korábban létezô lehetôség, miszerint kötelezố megindítani a köztisztviselô kérelmére a vele szembeni fegyelmi eljárást, ha ô ezáltal tisztázni akarja magát az alaptalan gyanúsításokkal szemben. Ugyanakkor a köztisztviselôi kar pozícióját gyengíti, hogy az új Kttv.-ból kikerült a szakszervezeti részvétellel történô hatékony érdekegyeztetés, a nyugat-európai jogokban meglévô kollektív közszolgálati jog.

Összehasonlítva a Kttv.-t a kontinentális európai országok szabályaival, a Kttv.-ben a szabályozás elvi szinten nem egységes jellegú. Bár a kontinentális nyugat-európai országokban az egyes szinteket (központi, regionális, körzeti és települési) külön törvények rendezik, azonban a rendezés elvei mindegyiknél egységesek. A Kttv. esetében ez nem mondható el. Az általános rendelkezéseket követôen szinte kazuisztikus jelleggel rendezi a Kttv. a kormánytisztviselók jogállását, amely után következik az autonóm szervek köztisztviselôire vonatkozó jogi rendezés az egyes hivatali szerveket érintôen, majd pedig az önkormányzati köztisztviselőket érintô jogi szabályozás. Míg azonban a kormánytisztviselőkre vonatkozó jogi szabályozás túl részletezó, és lényegében az 1992. évi korábbi Mt.-n alapul - ami viszont előnyös -, addig az önkormányzati köztisztviselôi jogi rendezés meglehetôsen elnagyolt és hézagos. Ezért, ha ez utóbbi területen joghézag támad, kénytelen a jogalkalmazó „belsó analógia” alapján a kormánytisztviselókre vonatkozó szabályokhoz nyúlni, és azokat analógiaszerúen alkalmazni. ${ }^{15} \mathrm{Az}$ ismétlôdések és a hiányosságok elkerülése, valamint a jobb áttekinthetôség érdekében az lenne a helyes, ha a Kttv.-ben egy általános rész készülne a kormánytisztviselókre vonatkozó általános jellegú szabályok kiemelésével. Ez tartalmazhatná a köztisztviselók általános jogait és kötelezettségeit, kiegészülve a szakszervezeti érdekegyeztetési és intézménytanácsi participációs rendszerrel. Ezt követôen pedig a különös rész fejezetekbe foglalva rendezné a kormány- és állami tisztviselôk, az országos autonóm hivatali, valamint az önkormányzati tisztviselôk jogainak és kötelezettségeinek egyes speciális kérdéseit.

A 2016. július 1-jétől hatályba lépett, állami tisztviselőkrôl szóló 2016. évi LII. törvény (Áttv.) tovább tagolta a közszféra szabályozását. Az új törvény hatálya a kormánytisztviselôket érintette, több lépésben átminôsítve ôket állami tisztviselôkké. Nem sokkal késôbb azonban az állami tisztviselôi intézményt a kormányzati igazgatásról szóló 2018:CXXV. tv. megszüntette, és visszaállt az egységes kormánytisztviselôi beosztás. A XVIII. fejezete az általánosan 4 hónapig terjedhetô munkaidókerettel több hétre szólóan napi 12 és heti 60 órára felemelhetôvé tette a munkaidôt, ami már 2015-tôl kezdve informálisan napi 9 és heti 45 óra. Ezenkívül a kormánytisztviselôk szabadságát is kurtította, mivel alapszabadságuk a korábbi 25 napról lecsökkent 20 napra. Mind- 
Jakab Nóra - Prugberger Tamás - Tóth Hilda: A magyar munka- és a közszolgálati...

ez szerintünk szembemegy a kormány gyermekvállalási és családvédelmi politikájával. Ugyanakkor e törvény miniszteri indoklása szerint a közigazgatásban szükséges egy új, a hatékonyságra orientáló életpályamodell, amelyben a díjazás alapja nagyobbrészt a tisztviselố teljesítményének a hatékonysága. Ezért egy új illetményrendszer bevezetése történt, amelyben az elômenetel elsôsorban nem a közszolgálatban töltött idô, hanem a teljesítmény függvénye. Az új törvény hatálya alá tartozó tisztviselók magasabb díjazásra váltak jogosulttá, mint a más közigazgatási szervnél foglalkoztatottak. Azonban az országos garantált bérminimum emelése 2017-tôl a másik közszolgálati törvény hatálya alá tartozó tisztviselôk illetményének a mértékét megemelte, így a különbség már nem jelentôs. A díjazással kapcsolatban a különbözô törvények hatálya alatt álló tisztviselók illetményét figyelembe véve, az egyenlô munkáért egyenlô bér elvének érvényesülése egyes kutatók szerint kétséges lehet (Mélypataki, 2017:370).

\section{A közalkalmazottakra vonatkozó szabályozás 2010 után}

Az 1992-ben hatályba lépett Kjt., bizonyos módosításokkal, a 2010-es kormányváltást követôen is hatályban maradt. A 2012. évi Kjt. novella (2012:LXXXVI. tv.) a közalkalmazottijogviszony-szabályozást azonban nem a köztisztviselóihez, hanem a Munka törvénykönyvéhez közelítette. Ez mutatkozik meg abban, hogy a novella kiiktatta a Kjt.-ból a fegyelmi eljárást, és helyette bevezette a rendkívüli felmentést. Az viszont pozitív, és egyúttal az Mt.-hez való közelítést is jelenti, hogy a Kjt.-be is bekerült a munkáltatói jogutódláshoz hasonló, a közfoglalkoztató-változással összefüggó közalkalmazotti jogviszony-módosulás, illetve a közalkalmazotti jogviszony megszúnésével járó munkaviszony-keletkeztetés. Ugyanakkor viszont távolodott az Mt.-tôl azáltal, hogy kiiktatta a foglalkoztató intézmény vagy munkakör átszervezése során öt vagy ennél több közalkalmazott leépítése esetén a csoportos létszámleépítés jellegú speciális szabályozást, ezzel gyengítve a közalkalmazottak egzisztenciális biztonságát.

Azzal, hogy a Kjt. 2012. évi novellájával a jogalkotó a közalkalmazotti jogot a munkajoghoz közelítette, számolni lehetett azzal, hogy a közintézményeknél folyó munkavégzésnek ezt a formáját a kormány megszüntetni tervezi. Ez a folyamat 2020 tavaszán kezdôdött el, amikor a kormány arról döntött, hogy a Budapesti Corvinus Egyetem után további hat egyetem múködését alapítványi formájúvá alakítja át. Ezzel az átalakítással együtt a kormány valamennyi alapítvánnyá átalakított egyetem minden oktatójának, tudományos munkatársának és ügyintézó-ügyviteli, valamint technikai személyzetének közalkalmazotti jogviszonyát az Mt. hatálya alá tartozó munkaviszonnyá alakítja át. Ezzel egy idôben ugyancsak az Országgyúlés elé került az a törvényjavaslat is, amely az összes állami fenntartású kulturális közintézmény - így múzeumok, levéltárak, könyvtárak, színházak és múvelôdési házak - korábbi közalkalmazotti státuszban dolgozójának jogviszonyát visszamenôlegesen és a jövôre nézve egyaránt szintén az Mt. hatálya alá tartozó munkaviszonnyá alakítja át. Ez a folyamat az osztrák jogfejlódéshez hasonlít, ahol az oktatási és kulturális intézményeknél közhivatalnoki jogviszonyban álló munkatársak jogviszonyát szintén munkajogviszonnyá alakítják át, ami azonban csak az újonnan létesüló jogviszonyokra vonatkozik, a korábban kinevezett közhivatal- 
nokok státuszát nem érinti. Ezenkívül az újonnan létesülő oktatási és kulturális közintézmények új munkaviszonya nem az általános munkajogi szabályozás, hanem a szerződéses szolgálati törvény (Vertragsbedienstetengesetz) hatálya alá tartozik. ${ }^{16}$ Ez pedig részben a kivezetés elôtt álló magyar közalkalmazotti törvényhez hasonló konstrukció.

\section{ÖsSZEGZÔ MEGÁLLAPÍTÁSOK}

Összegezve az eddigieket, a rendszerváltás után az elsố polgári kormány a közép- és kelet-európai posztkommunista régióban elsôként kodifikálta a nyugat-európai munka- és közszolgálati joghoz hasonlóan mind a két jogterületet, miközben e régió többi állama még csak a régi kódexeiknek az új követelményekhez történô hozzáigazításáig jutott el (vö. Prugberger, 1993; 1998). Az új magyar kodifikálás igyekezett összhangba hozni a munkáltatói és a munkavállalói érdekeket. Azonban az államadósság csökkentésére vagy kedvezô átütemezésére tett kísérlet hiánya, a nem megfelelố privatizálás, valamint a balliberális pártok hibás gazdaságpolitikája miatt az idóközi módosítások során egyre több szociális minimálstandard került ki az Mt.-ből és a Kjt.-ből, amivel viszont a jelenlegi polgári kormányzatnak sikerült a munkanélküliségi rátát tartósan $5 \%$ alá csökkenteni.

Ez azonban csak az érem egyik oldala. Az 1990-es rendszerváltást követố munkajogi szabályozásnak voltak árnyoldalai is. Árnyoldalként jelentkezett, hogy a sorozatos módosítások, amelyek mind az 1992. évi Mt.-t, mind pedig a 2012. évit érintették, fószabályként a munkavállalók érdekeinek a hátrányára valósultak meg, és a munkavállalók szociális védelmét érintố szabályokat szúkítették. Ezt egyértelmúen megvalósította az 1992. évi Mt.-t hatályon kívül helyezó 2012. évi módosítás, és különösen a 2018. évi decemberi novella. Ez a tendencia végigvonul mind a kollektív, mind az individuális munkajogon. Megmutatkozik abban, hogy a szociális piacgazdaság körülményei között az individuális munkajog tartalmi kérdéseit meghatározó kollektív munkajog a 2012. évi Mt.-ben az individuális munkajogi szabályok mögé kerül. Emellett a munkavállalói érdekvédelmet országosan is lefedni tudó, szakszervezeti részvételú tarifajog és kollektív szerződés a jóval szúkebb, csak egy üzemre kiterjedô érdekvédelem, Magyarországon a nyugat-európai államokhoz viszonyítva csak formális üzemi tanácsi intézményrendszer szabályozása mögé szorul. A 2012. évi Mt. egyértelmúen szúkíti és gyengíti a szakszervezeti jogokat, az üzemi tanácsnak a munkáltatóval történô korábban is szúkös együttdöntési jogát pedig formálissá zsugorította. Az országos általános érdekegyeztetést felszámolták, és csak az országos és területi ágazati érdekegyeztetés maradt meg.

Az individuális munkajognál láttuk, hogy egyértelmúen munkáltatói érdekeknek felel meg a munkaidőre és a két munkanap közötti pihenôidőre vonatkozó szabályozás, mely utóbbinál fennáll az irányelv által biztosított 11 óra, a korábbi szabályozással egyezôen, az új magyar Mt.-ben 8 órára történô lecsökkentésének lehetôsége. Egyértelmúen munkáltatói érdekeknek felel meg a munkaidôre vonatkozó szabályozás, abban a túlmunka és a rendkívüli munkavégzés tágításának, igaz, kölcsönös megállapodással történô lehetôsége, amit azonban a munkáltató ki tud kényszeríteni. Viszont a 
Jakab Nóra - Prugberger Tamás - Tóth Hilda: A magyar munka-és a közszolgálati...

hétvégi két pihenőnap biztosítása a nyugat-európai nemzeti szabályokban megjelenô másfél napi irányelvi szabályozáshoz képest méltányos. Az is kedvezô, hogy a nôket szülés után, gyermekük hároméves koráig kérelmükre részmunkaidóben kell foglalkoztatni. A részmunkaidôben dolgozó munkavállalókat azonban a munkáltató bármikori behívással rendszertelen munkaidóvel is foglalkoztathatja, ami alól nem kivételek a 3 év alatti gyermeküket neveló anyák, holott az ilyen korú gyermekeknél a velük való rendszeres foglalkozás alapvetô körülmény. Itt tehát az új szabályozás részben jó, részben viszont nem. A nyugat-európai jogokkal egyértelmúen szembemegy viszont a munkáltatót a munkavállalóval, a munkavállalót pedig a munkáltatóval szemben terhelô anyagi felelôsségi szabályok. A korábbi magyar és a nyugat-európai államok e téren fennálló ama elóírásaival szemben, melyben a munkáltató szigorúbb szabályok szerint felel a munkavállalónak okozott kárért, viszont a munkavállaló felelôssége a munkáltatóval szemben enyhébb, az új Mt. a munkáltatóét csökkentette, a munkavállalóét pedig egy szintre hozta a munkáltatóéval. Ugyanakkor a munkaviszony megszüntetésére vonatkozó új magyar szabályozás kirívóan és antiszociálisan munkáltatópárti jellege súlyosan sérti a munkavállalók jogait.

Mindebből végsố megállapításként leszúrhetô, hogy a magyar munkajogi szabályozás a rendszerváltozás idôszakában sokat változott. Többségében a munkavállalók hátrányára, némely esetben a munkavállalók előnyére, és vannak olyan szabályok, amelyek részben elônyösek, részben viszont hátrányosak a munkavállalók számára. Ebból az túnik ki, hogy a magyar munkajogi szabályozás a szociális államot lebontó mai eurotranszatlanti neoliberális irányzatának igyekszik megfelelni, fóleg azért, hogy külföldi cégek egyes részlegei Magyarországra települjenek. A jogalkotó azonban a munkavégzés hatékonyságát a kormányzati munkában is biztosítani kívánja. Ezért alkotta meg a kormányzati igazgatásról szóló 2018:CXXV. tv.-t, amelynek alapján a kormánytisztviselók szolgálati viszonya is jelentôsen közeledett a munkajoghoz, mivel megszúntek a korábbi közszolgálati privilégiumaik. Ha „de jure” nem is, „de facto” azonban majdnem olyan helyzet állt elô, mint 1990 elôtt, amikor ugyanaz a szabályozás volt érvényes a gazdasági és a közszolgálati munka világában.

\section{JEGYZETEK}

1 A tanulmány a Nemzeti Kutatási Fejlesztési és Innovációs Hivatal támogatásával (K120158 kutatási témapályázat keretében) az NKFI Alapból valósult meg. Az anyaggyújtésben részt vett dr. Szôllôs Andrea ügyvéd, PhD-hallgató, Miskolci Egyetem.

2 Konferencia a közszolgálat egységes jogi szabályozásáról, 1997. május. Elôadó: Kiss György, Vadász János, Horváth István, Kollonay Csilla, Radnay József és Prugberger Tamás hozzászólásai.

3 Mt. 33. §.

4 A SZOT tulajdonában álló vagyon megosztását a szakszervezeti vagyon védelmérôl, a munkavállalók szervezkedési és szervezeti esélyegyenlőségérôl szóló 1991. évi XXVIII. törvény 7. §-a, valamint az érdekszövetségek között megkötött megállapodás szabályozta.

5 Mt. 49. § (3)-(4) bekezdések.

6 Lásd bôvebben Prugberger, 2009; Prugberger-Jakab-Zaccaria, 2016.

7 Az 1992. évi Mt.-nek a 2005:VIII. tv.-nyel történt módosítását követô átmeneti állapot 118/A. § (3) bek., majd a 2011-ben történt újabb módosítással revideált állapot 117/B. § (3) bek. 


\section{Polgári Szemle · 16. évfolyam 1-3. szám}

8 A nyugat-európai államokban a köztisztviselóket és közalkalmazottakat csak fegyelmi eljárással lehet állásuktól megfosztani. Vö. Veszprémi, 2012. 3. fejezet; Peine-Heinlein, 1999:109-110 .

$9 \quad$ E javaslat részletes kifejtése Prugbergernél (2010).

10 Lásd a Bizottság közleményét a rugalmas biztonság közös elveinek a kidolgozásáról: COM(2007) 359. A rugalmas biztonság célja annak biztosítása, hogy az EU valamennyi polgára magas szintú foglalkoztatási biztonságot élvezhet, azaz lehetôsége van arra, hogy nyugdíjba vonulásáig élete minden szakaszában könnyen találjon munkát, és kedvezô foglalkoztatási kilátásai legyenek a gyorsan változó gazdasági környezetben. A rugalmas biztonság célja emellett az, hogy mind a munkaadókat, mind a munkavállalókat segítse a globalizáció előnyeinek kiaknázásában.

11 Az önálló munkavégzô vállalkozásának szabadságáról mint alapjogról lásd Kiss, 2006:285-290. A doktori értekezés 2010-ben nyomtatásban is megjelent: Kiss György (2010): Alapjogok kollíziója a munkajogban. Justus Tanácsadó Bt., Pécs. A továbbiakban azonban a doktori értekezés szövegét vettük alapul. Lásd még Kiss, 2005:116.

12 2012: I. tv. (Mt.) 141. §-a. Megjegyezzük, hogy e múszakpótlék fogalmát és tól-ig fennálló idôpontját helyes lett volna az Mt. XI. fejezete 46. pontjának (fogalmak) 89. §-a (2) bekezdésében rendezni.

13 E jogterület bôvebb kritikai kielemzését lásd Prugberger, 2018.

14 Bôvebb kritikáját mindennek lásd Prugberger-Rácz, 2017:191-192, 195.

15 Bôvebben lásd errôl Prugberger, 2014a.

16 Kodex des österreichischen Rechts, Arbeitsrecht 24. Aufl. Stand I. 9. 2002. 27. ff. p. Citálja Veszprémi, 2012a:20.

\section{FELHASZNÁLT IRODALOM}

Balázs István (1992): A közszolgálati jogviszony személyi hatálya a világ fóbb közszolgálati rendszereiben. Magyar Közigazgatás, 42. évf., 2. sz., 78-88.

Birk, Rolf (1997): Die Massenentlassung nach europaischem und nationalem Recht. In: Csák Csilla (szerk.): Ünnepi tanulmányok Prugberger Tamás professzor 60. születésnapjára. Novotni Kiadó, Miskolc, 23-35.

Bódis Lajos (1994): Munkaügyi kapcsolatok állami szerepvállalással. Európa Fórum, 4. évf., 4. sz., 73-91.

Borbély Szilvia (1994): A spanyol érdekegyeztetési etalon. Európa Fórum, 4. évf., 4. sz., 92-103.

Deli Petra Eszter (2013): A munkavállaló általános felelôssége a német és az osztrák modell jog-összehasonlító keresztmetszetében. PhD-értekezés, Szegedi Tudományegyetem, Szeged.

EC (2006): Zöld Könyv. A munkajog korszerúsítése szembenézve a XXI. század kihívásaival. COM(2006)708, http:/ / ec.europa.eu/transparency/regdoc/rep/1/2006/HU/1-2006-708-HU-F1-1.Pdf.

Eörsi Gyula (1961): A jogi felelősség alapproblémái. Akadémiai Kiadó, Budapest.

Ficzere Lajos (1970): Az állami vállalat a gazdaságirányítás új rendszerében. Közgazdasági és Jogi Könyvkiadó, Budapest.

Fodor T. Gábor (2016): A Munka Törvénykönyve munka- és pihenőidô-szabályozásának uniós jogi megfelelésérôl. Magyar Munkajog, 3. évf., 2. sz., 21-36.

Gyulavári Tamás (szerk.) (2015): Munkajog. ELTE Eötvös Kiadó, Budapest.

Heerma van Voss, G. J. J. (2003): Nederlands social recht. Boom Juristische uitgevers, Den Haag.

Hegedús István (1973): A szövetkezeti tagsági viszony jogi alapkérdései. Közgazdasági és Jogi Könyvkiadó, Budapest.

Hennsler, Martin - Frik, Roman (2003): Arbeitnehmerbeteiligung in den USA durch Betriebsräte. NZA. 11.

Horváth István (2009): Befagyasztott ambivalenciák. A közalkalmazotti és köztisztviselôi illetményrendszer szabályozási ellentmondásai, Magyar Jog, 56. évf., 12. sz., 759-766.

Jakab Nóra (2017): Gondolatok a rugalmasság és biztonság egyensúlyáról Prugberger Tamás 80. születésnapja alkalmából. Miskolci Jogi Szemle. 12. évf., 2. sz., 213-227.

Kenderes György - Prugberger Tamás - Tatár Irén (1989): Jogszabály-kriticizmus. Jelzố, 1. sz.

Kenderes György - Prugberger Tamás (1993): A közalkalmazotti és a köztisztviselői jogviszony új jogi szabályozása. Magyar Közigazgatás, 43. évf., 6. sz., 329-335. 
Jakab Nóra - Prugberger Tamás - Tóth Hilda: A magyar munka- és a közszolgálati...

Kenderes György - Prugberger Tamás (1991): A közszolgálat, a közalkalmazás és a köztisztviselés a tervbe vett új jogi szabályozás tükrében. Magyar Közigazgatás, 41. évf., 10. sz., 908-917.

Kiss György (1988): Az egységes közszolgálati törvény szabályozásának lehetséges módjai. Kézirat.

Kiss György (1998): Az egységes közszolgálat szabályozásának koncepcionális problémái. In: Koncepció a közszolgálatban foglalkoztatottakra vonatkozó szabályozás egységesitésének a lehetôségérôl. SZEF Kiadó, Budapest.

Kiss György (2005): Munkajog. Osiris Kiadó, Budapest.

Kiss György (2006): Alapjogok kolliziója a munkajogban. Akadémiai doktori értekezés, Pécs.

Kokoly Zsolt (2006): A csoportos létszámcsökkentés a román munkajogban. Magyar Jog, 53. évf., 12. sz., $758-763$.

Kostecka, Jan (1992): Neugestaltung des kollektiven Arbeitsrechts.in der CSRF. Arbeit und Recht. No. 11.

Mélypataki Gábor (2017): Egyenlő munkáért egyenlőtlen bér - észrevételek a tisztviselői illetményrendszer változásaihoz. Miskolci Jogi Szemle. 12. évf., 2. sz., 367-375.

Nagy László (1964): Anyagi felelôsség a munkaviszony keretében okozott károkért. Közgazdasági és Jogi Könyvkiadó, Budapest.

NZA (2000): Rechtsprechung. Neue Zeitschrift für Arbeitsrecht, Vol. 17, No. 22, 1227-1228.

NZA (2004): Rechtsprechung. Neue Zeitschrift für Arbeitsrecht, Vol. 21, No. 3, 164-170.

Ojeda Aviles, Antonio - Perez, Manuel (1989): Gewerkschaftsrechte im Betrieb nach spanischem Recht. Arbeitsrecht im Betrieb, No. 12.

Peine, Franz Joseph - Heinlein, Dieter (1999): Beamtenrecht. C. F. Müller Verlag, Heidelberg.

Prugberger Tamás (1992): Összehasonlító munkajog. Akademie der Angewandten Wissenschaften (ADAW). Bonn-Budapest.

Prugberger Tamás (1993): A munkajogi szabályozás átalakulása a szomszédos, volt reálszocialista közép- és kelet-európai országokban. Munkaügyi Szemle, 12. sz.

Prugberger Tamás (1998): A munkajog átalakulása a kelet-közép-európai régióban. Valóság, 41. évf., 9. sz., 103-116.

Prugberger Tamás (2007): A közszolgálati jog magánjogi jellegûvé tételének és a munkajogba olvasztásának kérdéséhez. Közigazgatási Szemle, 1. évf., 1. sz., 16-26.

Prugberger, Tamás (2008): Kündigungs- und Massenentlassungsregelungen in Ungarn und in den postkommunistischen Nachbarländern Ungarns. In: Konzen, Horst et al. (Hrsg.): Festschrift für Rolf Birk zum siebzigsten Geburstag. Mohr Siebert, Tübingen, 643-658.

Prugberger Tamás (2009): Az európai uniós munkajogi szabályozás módosulásainak és kiegészítéseinek kihatása a munkavállalók szociális érdekeire. Európai Jog, 9. évf., 4. sz., 20-27.

Prugberger Tamás (2010): A közszolgálati jog újraszabályozásának problémája. Új Magyar Közigazgatás, 3. évf., 5. sz., 43-50.

Prugberger Tamás (2013): Magyar munka-és közszolgálati jogi reform európai kitekintéssel. Novotni Kiadó, Miskolc (3. bôvített kiadás és 3. bôvített utánnyomás).

Prugberger Tamás (2014a): A közszolgálat jogdogmatikai és rendszerelvszerú egységes szabályozásának problematikája. Új Magyar Közigazgatás, 7. évf., 4. sz., 1-8.

Prugberger Tamás (2014b): A munkaviszonyból eredô kártérítési felelôsség újraszabályozásának néhány problematikus vonása a 2012: I. törvényben. Gazdasági Élet és Társadalom, 6. évf., 1-2. sz., 144-157.

Prugberger Tamás (2018): A kiküldési irányelv és a magyar jogi szabályozás. Gazdaság és Jog, 26. évf., 6. sz., 24-27.

Prugberger Tamás - Tatár Irén (1994): A munkaküzdelem jogi szabályozása. Európa Fórum, 4. évf., 2. sz., 114-124.

Prugberger Tamás - Kenderes György - Mélypataki Gábor (2012): A munka-és közszolgálati jog intézményrendszerének kritikai és összehasonlító elemzése. Novotni Kiadó, Miskolc.

Prugberger Tamás - Nádas György (2014): Európai és magyar összehasonlító munka-és közszolgálati jog. Wolters Kluwer, Budapest.

Prugberger Tamás - Nádas György (2015): Európai és magyar összehasonlító kollektív munkajog. Wolters Kluwer Kiadó, Budapest. 


\section{Polgári Szemle 1 16. évfolyam 1-3. szám}

Prugberger Tamás - Jakab Nóra - Zaccaria Márton Leó (2016): Az európai munkajog vázlata - Abriss des europaisches Arbeitsrecht. Novotni Alapítvány - Licium Art, Debrecen.

Prugberger Tamás - Rácz Zoltán (2017): A munka- és a közszolgálati jogi érdekegyeztetés alakulása 2010 után. Polgári Szemle, 13. évf., 4-6. sz., 184-201, https://doi.org/10.24307/psz.2017.1215.

Prugberger Tamás - Tóth Hilda (2019): A 2012. évi Munka Törvényének egy újabb módosítása a rendkívüli munkavégzés korlátainak tágítása érdekében. Jogtudományi Közlöny, 74. évf., 1. sz., 25-30.

Rens, Johan van (1992): A munkaügyi kapcsolatok holland modellje. Európa Fórum, 2. évf., 4., 19-27.

Sipka Péter (2015): A munkáltatói kárfelelósség alakulása a bírói gyakorlat tükrében. HVG-ORAC Kiadó, Budapest.

Sipka Péter - Zaccaria Márton Leó (2016): Dolgozik és pihen? A munkaidô fogalmának bôvítése az Európai Unió bíróságának újabb ítélete nyomán, tekintettel a magyar bírói gyakorlatra. Jogtudományi Közlöny, 71. évf., 9. sz., 449-457.

Sredkova, K. (1995): Das bulgarische Arbeitgesetzbuch auf dem Wege der Reformen. Zeitschrift für Internationale Arbeits- und Sozialrecht (ZIAS), No. 2.

Tatár Irén - Kenderes György - Prugberger Tamás (1989): (El)tervezett sztrájkjog. Élet és Tudomány, 44. évf., 1. sz., 8-9.

Tóth Hilda (2017): Rugalmas biztonság elve a munkaviszony megszüntetése során. Miskolci Jogi Szemle, 12. évf., 2. sz., 620-630.

Vadász János (2006): Közszolgálati reform. Kossuth Kiadó, Budapest.

Venediktov, A. V. (1948): Az állami szocialista tulajdon. Moszkva, Kézirat, MTA Jogtudományi Intézet Könyvtára.

Veszprémi Bernadett (2012a): A köztisztviselók felelôsségi rendszere. Debreceni Egyetemi Kiadó, Debrecen.

Veszprémi Bernadett (2012b): Felelôsség a közszolgálatban. Debrecen Egyetemi Kiadó, Debrecen.

Zaccaria Márton Leó (2013): Fogalmi változások a munkaidố kapcsán az új munka törvénykönyvében. Miskolci Jogi Szemle, 8. évf., 1. sz., 130-142. 